Prepared in cooperation with the U.S. Army Corps of Engineers

\title{
Control-Structure Ratings on the Chicago Sanitary and Ship Canal near Lockport, Illinois
}

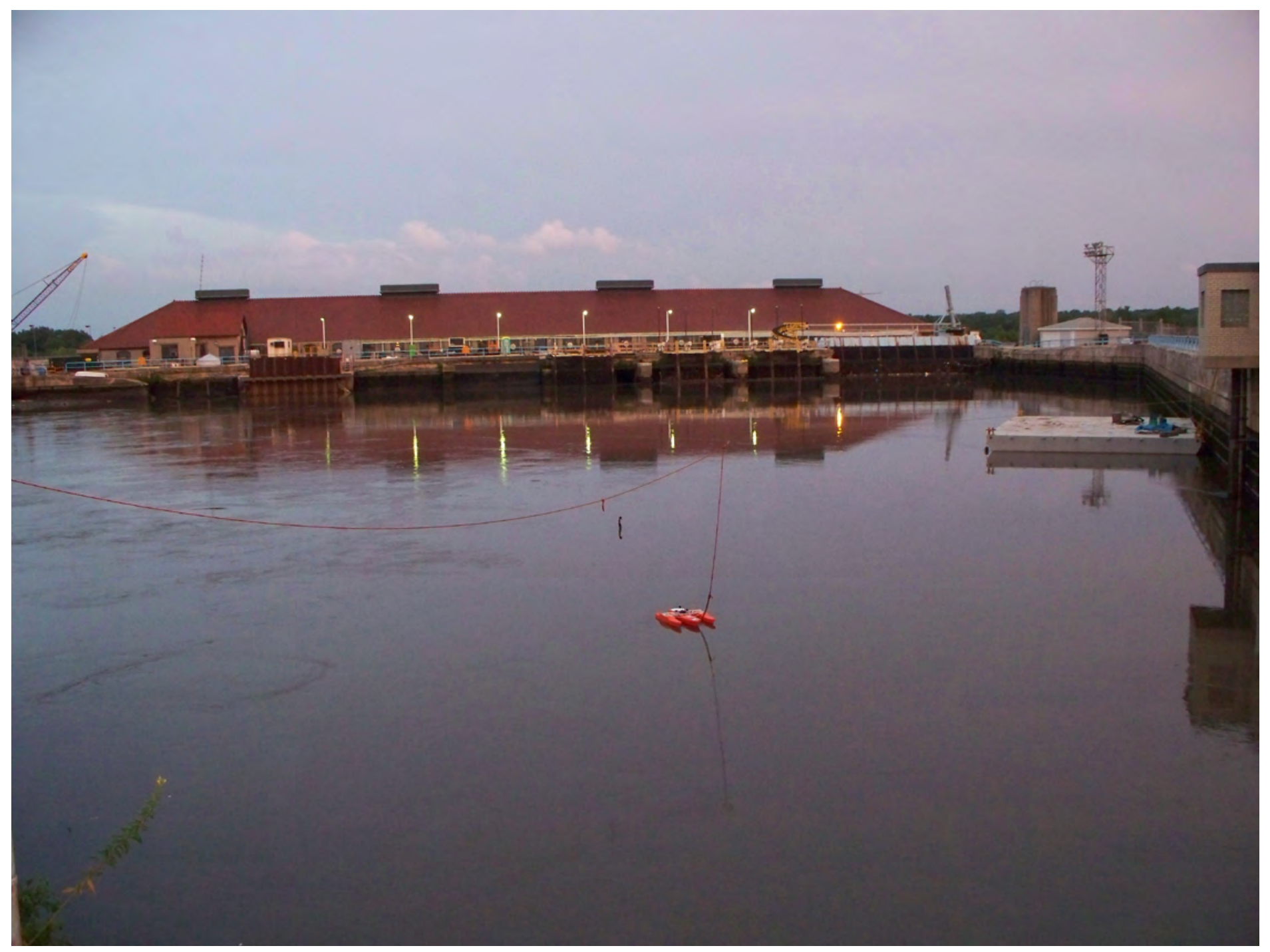

Scientific Investigations Report 2012-5131 


\section{Cover photograph:}

Lockport Powerhouse (photo taken looking downstream on July 24, 2010) 


\section{Control-Structure Ratings on the Chicago Sanitary and Ship Canal near Lockport, Illinois}

By Timothy D. Straub, Kevin K. Johnson, Jon E. Hortness, and James J. Duncker

Prepared in cooperation with the U.S. Army Corps of Engineers

Scientific Investigations Report 2012-5131 


\title{
U.S. Department of the Interior \\ KEN SALAZAR, Secretary \\ U.S. Geological Survey \\ Marcia K. McNutt, Director
}

\author{
U.S. Geological Survey, Reston, Virginia: 2012
}

For more information on the USGS - the Federal source for science about the Earth, its natural and living resources, natural hazards, and the environment, visit http://www.usgs.gov or call 1-888-ASK-USGS.

For an overview of USGS information products, including maps, imagery, and publications, visit http://www.usgs.gov/pubprod

To order this and other USGS information products, visit http://store.usgs.gov

Any use of trade, firm, or product names is for descriptive purposes only and does not imply endorsement by the U.S. Government.

Although this information product, for the most part, is in the public domain, it also may contain copyrighted materials as noted in the text. Permission to reproduce copyrighted items must be secured from the copyright owner.

Suggested citation:

Straub, T.D., Johnson, K.K., Hortness, J.E., and Duncker, J.J., 2012, Control-structure ratings on the Chicago Sanitary and Ship Canal near Lockport, Illinois: U.S. Geological Survey Scientific Investigations Report 2012-5131, 25 p. 


\section{Acknowledgments}

The authors acknowledge Jim Stiman of the U.S. Army Corps of Engineers (USACE) for supporting the use of advanced methodologies and providing technical assistance during this study. The authors also acknowledge Jim Yurik, Martin Castro, and Phil Nieman of the Metropolitan Water Reclamation District of Greater Chicago (MWRD) for their assistance with the coordination of gage installation and gate-opening information, along with overall technical support regarding the structures. The authors acknowledge Tzuoh-Ying Su, USACE, and Chad Wagner, U.S. Geological Survey (USGS), for their technical assistance and reviews of the report. Finally, the authors acknowledge the following USGS colleagues: Jennifer Sharpe, for report illustrations development; and Mark Lynch, Ryan Beaulin, Greg Goodwin, John Goossen, and Mike Lee for making the streamflow measurements. 


\section{Contents}

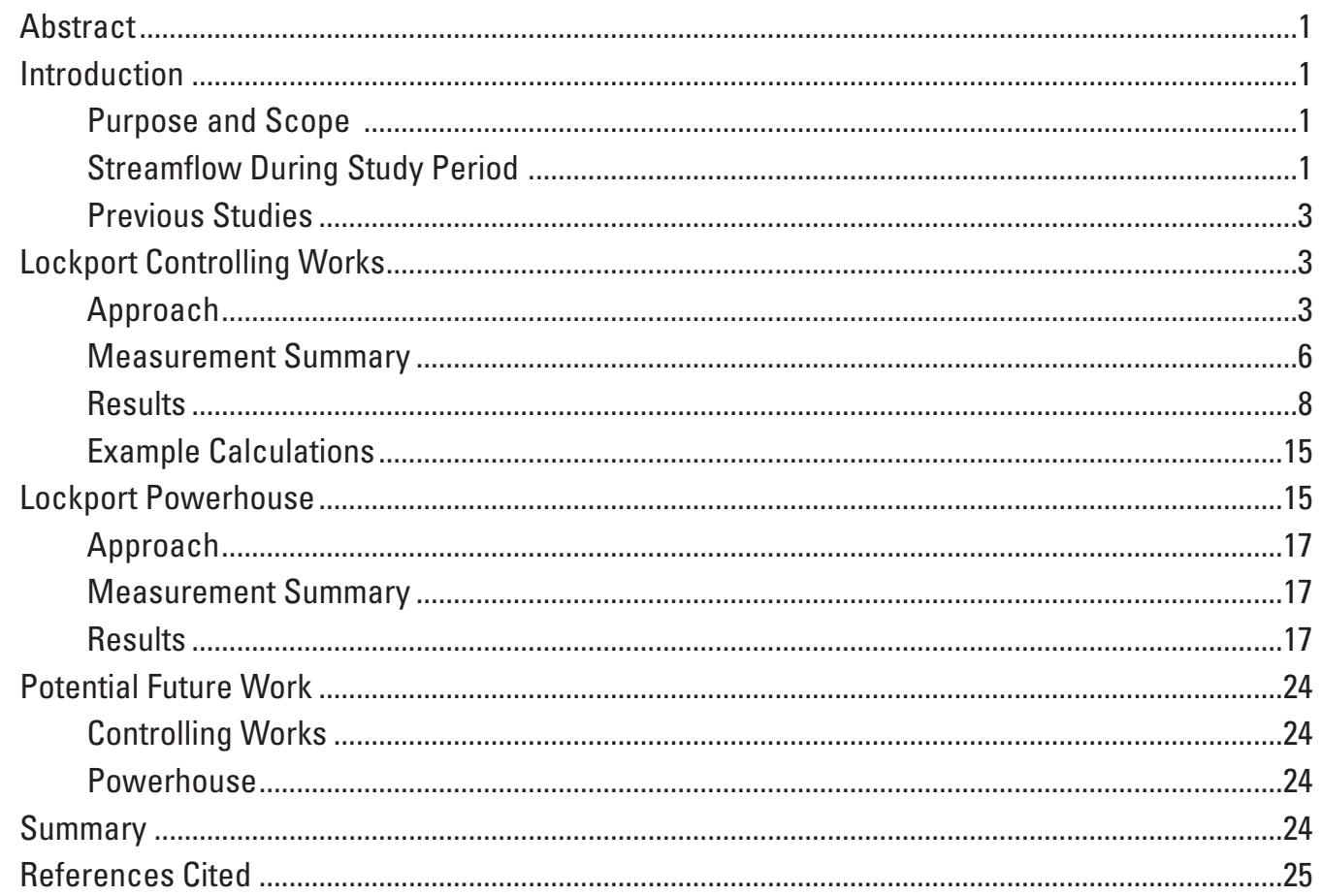

\section{Figures}

1. Map showing location of the Lockport Powerhouse and Controlling Works and overview of drainage into the Chicago Sanitary and Ship Canal and Des Plaines River, Illinois.

2. Aerial image of the Lockport Powerhouse, Controlling Works, and Des Plaines River, Illinois, streamgages used to determine flow through the Lockport Controlling Works

3. Aerial image of the Lockport Controlling Works and headwater gages and Des Plaines River at Lockport, Illinois, streamgage

4. Photographs showing $A$, view looking upstream on the ship canal at the controlling works with all gates closed; and $B$, view looking downstream from the structure toward the Des Plaines River, Illinois

5. Photographs showing controlling works with all seven gates open on May 13, 2010, between 11:00 and 12:00 CST. $A$ and $B$, view looking upstream on the ship canal at the controlling works headwater conditions. $C$, view at the downstream side of the controlling works. $D$, view looking upstream at the Des Plaines River at Lockport, Illinois, streamgage with downstream side of controlling works in the distance.

6. Photographs showing controlling works with five gates open on July 24,2010 , at approximately 15:00 CST. $A$, view of the downstream side of the controlling works. $B$, view looking upstream at the Des Plaines River at Lockport, Illinois, streamgage with downstream side of controlling works in the distance. 
7. Schematic (side view) of the Controlling Works sluice gates on the Chicago Sanitary and Ship Canal at Lockport, Illinois

8. Graphs showing discharge coefficient for $A$, free-weir flow and $B$, submerged-weir flow, and the headwater depth for the controlling works sluice gates on the Chicago Sanitary and Ship Canal near Lockport, Illinois.

9. Comparison of continuous-flow data measured at U.S. Geological Survey streamflow-gaging stations and flow computed using the 2011 equations for the controlling works sluice gates on the Chicago Sanitary and Ship Canal near Lockport, Illinois..

10. Flow per controlling works sluice gate and headwater elevation for 1947, 1985, and 2011 ratings and illustrating, $A$, the 2011 ratings should be used only for the headwater elevations ranging from -7.0 to -10.5 feet Chicago City Datum, which is the elevation range that the data were collected and, $B$, that use of 2011 ratings in the shaded zone above -7.0 feet might result in erroneous flow values.

11. Controlling works continuous-flow data measured at U.S. Geological Survey streamflow-gaging stations and flow computed using 1947, 1985, and 2011 methods...

12. Aerial image of Lockport Powerhouse structures and headwater and tailwater gages

13. Photographs showing Lockport Powerhouse structures. $A$, view looking downstream at structure and acoustic Doppler current profiler measurement being made on July 24,2010 , utilizing the fenderwall. $B$, fenderwall during dry conditions in 1907

14. Lockport bay section showing the intricacies of flow..

15. Photographs showing Lockport Powerhouse headwater and tailwater conditions on July 24, 2010. $A$, view downstream at headwater conditions of sluice gates $3 \mathrm{~A}$, $B$, and $C ; 4 A, B$, and $C$; and turbine gates 1 and 2 at 17:30 CST. $B$, conditions upstream and downstream of trash guard for sluice gate $4 C$. $C$, view of tailwater conditions downstream of the Lockport Powerhouse at 19:15 CST..

16. Measured and computed flows for the Lockport Powerhouse on the Chicago Sanitary and Ship Canal near Lockport, Illinois.

17. Selected photographs (from Muga, 1961) showing Lockport Powerhouse flow conditions as modeled by Muga, 1961

\section{Tables}

1. Statistical summary of streamflow for the U.S. Geological Survey streamflowgaging station on the Des Plaines River at Riverside, Illinois.

2. Streamflow measurements during the study period for the U.S. Geological Survey streamflow-gaging station at Des Plaines River at Lockport (DPR-L), Illinois

3. Streamflow measurements during the study period for the U.S. Geological Survey streamflow-gaging station at Des Plaines River at Division Street at Lockport (DPR-DSL), Illinois.

4. Number of gates open and flow conditions for two storm events when the controlling works at Lockport, Illinois, were in operation....

5. Flow measurements during the study period for the U.S. Geological Survey streamflow-gaging station at the Chicago Sanitary and Ship Canal at Lockport (CSSC-LPH), Illinois, and computed flows from Hart and McGee (1985) and the Metropolitan Water Reclamation District. 


\section{Conversion Factors and Vertical Datum}

\begin{tabular}{lcl}
\hline \multicolumn{1}{c}{ Multiply } & By & \multicolumn{1}{c}{ To obtain } \\
\hline foot $(\mathrm{ft})$ & Length & \\
mile $(\mathrm{mi})$ & 0.3048 & meter $(\mathrm{m})$ \\
\hline & 1.609 & kilometer $(\mathrm{km})$ \\
\hline square foot $\left(\mathrm{ft}^{2}\right)$ & Area & \\
square foot $\left(\mathrm{ft}^{2}\right)$ & 929.0 & square centimeter $\left(\mathrm{cm}^{2}\right)$ \\
square mile $\left(\mathrm{mi}^{2}\right)$ & 0.09290 & square meter $\left(\mathrm{m}^{2}\right)$ \\
square mile $\left(\mathrm{mi}^{2}\right)$ & 259.0 & hectare $($ ha) \\
\hline & 2.590 & square kilometer $\left(\mathrm{km}{ }^{2}\right)$ \\
\hline foot per second $(\mathrm{ft} / \mathrm{s})$ & Velocity & \\
\hline & .3048 & meter per second $(\mathrm{m} / \mathrm{s})$ \\
\hline cubic foot per second $\left(\mathrm{ft}^{3} / \mathrm{s}\right)$ & Flow rate & \\
\hline
\end{tabular}

Vertical coordinate information is referenced to the Chicago City Datum (CCD); $0 \mathrm{ft} \mathrm{CCD} \mathrm{equals}$ $579.48 \mathrm{ft}$ National Geodetic Vertical Datum of 1929 (NGVD29).

A water year (WY) is the 12-month period from 0ctober 1 through September 30 and is designated by the calendar year in which it ends. For example, WY 2010 is from October 1, 2009, to September 30, 2010.

\section{Abbreviations}

$\begin{array}{ll}\text { ADCP } & \text { acoustic Doppler current profiler } \\ \text { CCD } & \text { Chicago City Datum } \\ \text { CSSC } & \text { Chicago Sanitary and Ship Canal } \\ \text { CSSC-LCW } & \text { Chicago Sanitary and Ship Canal Lockport Controlling Works } \\ \text { CSSC-LPH } & \text { Chicago Sanitary and Ship Canal at Lockport (powerhouse gage) } \\ \text { DPR-L } & \text { Des Plaines River at Lockport } \\ \text { DPR-DSL } & \text { Des Plaines River at Division Street at Lockport } \\ \text { FW } & \text { free weir } \\ \text { LCW } & \text { Lockport Controlling Works } \\ \text { MWRD } & \text { Metropolitan Water Reclamation District of Greater Chicago } \\ \text { NWIS } & \text { National Water Information System } \\ \text { SW } & \text { submerged weir } \\ \text { USACE } & \text { U.S. Army Corps of Engineers } \\ \text { USGS } & \text { U.S. Geological Survey } \\ \text { WSE } & \text { water-surface elevation } \\ \text { WY } & \text { water year }\end{array}$




\title{
Control-Structure Ratings on the Chicago Sanitary and Ship Canal near Lockport, Illinois
}

\author{
By Timothy D. Straub, Kevin K. Johnson, Jon E. Hortness, and James J. Duncker
}

\section{Abstract}

The U.S. Army Corps of Engineers and the Metropolitan Water Reclamation District of Greater Chicago regulate flows through control structures along the Lake Michigan lakefront and the Chicago Sanitary and Ship Canal (CSSC) for Lake Michigan diversion accounting, flood control, sanitary, and navigation purposes. This report documents the measurement and computation of flow through the Lockport Controlling Works (LCW) and the Lockport Powerhouse. This analysis aided in evaluation of the ratings at both structures, and the development of new ratings at the controlling works.

The LCW structure consists of seven 30 -feet (ft) wide sluice gates and is used to divert water from the CSSC and into the Des Plaines River. The flow regimes for the sluice gate included both free and submerged weir. Forty and 491 flow values from U.S. Geological Survey streamflow-gaging stations were used to develop equations describing free- and submerged-weir flow, respectively, through the sluice gates. The equations were developed for canal headwater elevations ranging from -7.0 to $-10.5 \mathrm{ft}$ Chicago City Datum (CCD), and tailwater (Des Plaines River at Lockport) to headwater (CSSCLCW-Base) ratios ranging from 0.31 to 0.66 .

The Lockport Powerhouse structure consists of nine 9-ft wide by 14-ft high sluice gates and two 10-ft diameter turbines. Both tailwater and no-tailwater effect flow regimes occurred during nine measurements. Also, the canal headwater elevations ranged from -2.74 to $-8.45 \mathrm{ft} \mathrm{CCD}$, and the gates were configured six different ways during the measurements.

\section{Introduction}

The U.S. Army Corps of Engineers (USACE) and the Metropolitan Water Reclamation District of Greater Chicago (MWRD) regulate flows through control structures along the Lake Michigan lakefront and the Chicago Sanitary and Ship Canal (CSSC). New acoustic technologies for measuring velocity and flow are being used to determine flow for Lake Michigan diversion accounting, flood control, sanitary, and navigation purposes. For example, periodic acoustic Doppler current profiler (ADCP) measurements are used to determine flow and an acoustic side-looker measurement device is used to provide continuous velocity data for a velocity-index rating at the streamgage near Lemont, Illinois (05536890) (fig. 1). These advanced technologies provide an opportunity to evaluate the ratings for flow through the control structures near Lockport, Illinois (fig. 1). The evaluation and analysis were done in 2010 and 2011 by the U.S. Geological Survey (USGS), in cooperation with the USACE.

\section{Purpose and Scope}

This report documents the measurement of flow through the Lockport Controlling Works (LCW) (7 sluice gates) and the Lockport Powerhouse (9 sluice gates and 2 turbines) utilizing acoustic technology. At both locations, the existing ratings were evaluated for as many gates as were open at the time of two storm events (May 13, 2010, and July 24-25, 2010). At each location, all the gates were not necessarily open during the events because of operational procedures, gate malfunctions, or replacement of gates. Flow data from streamflowgaging stations enabled new ratings to be developed for the controlling works.

Flow measurements on the Des Plaines River were completed for a wide range of canal stages during two storm events when the controlling works gates and (or) powerhouse gates were operational during March-November 2010. Three of the nine sluice gates at the powerhouse were undergoing repairs throughout the measurement time period, while others were not always in operation during measurements. All seven controlling works sluice gates were open during the first storm, and five gates were open during the second storm.

\section{Streamflow During Study Period}

A statistical summary of streamflow at a long-term USGS streamflow-gaging station on the Des Plaines River at Riverside, Illinois (05532500), during the study for water year (WY) 2010 is presented in table 1 and compared to statistics for the full period of record (WY 1944-2010) at this station. The summary shows that both low and high streamflows occurred during the data-collection period, including a peak streamflow within 15 percent of the peak of record. 


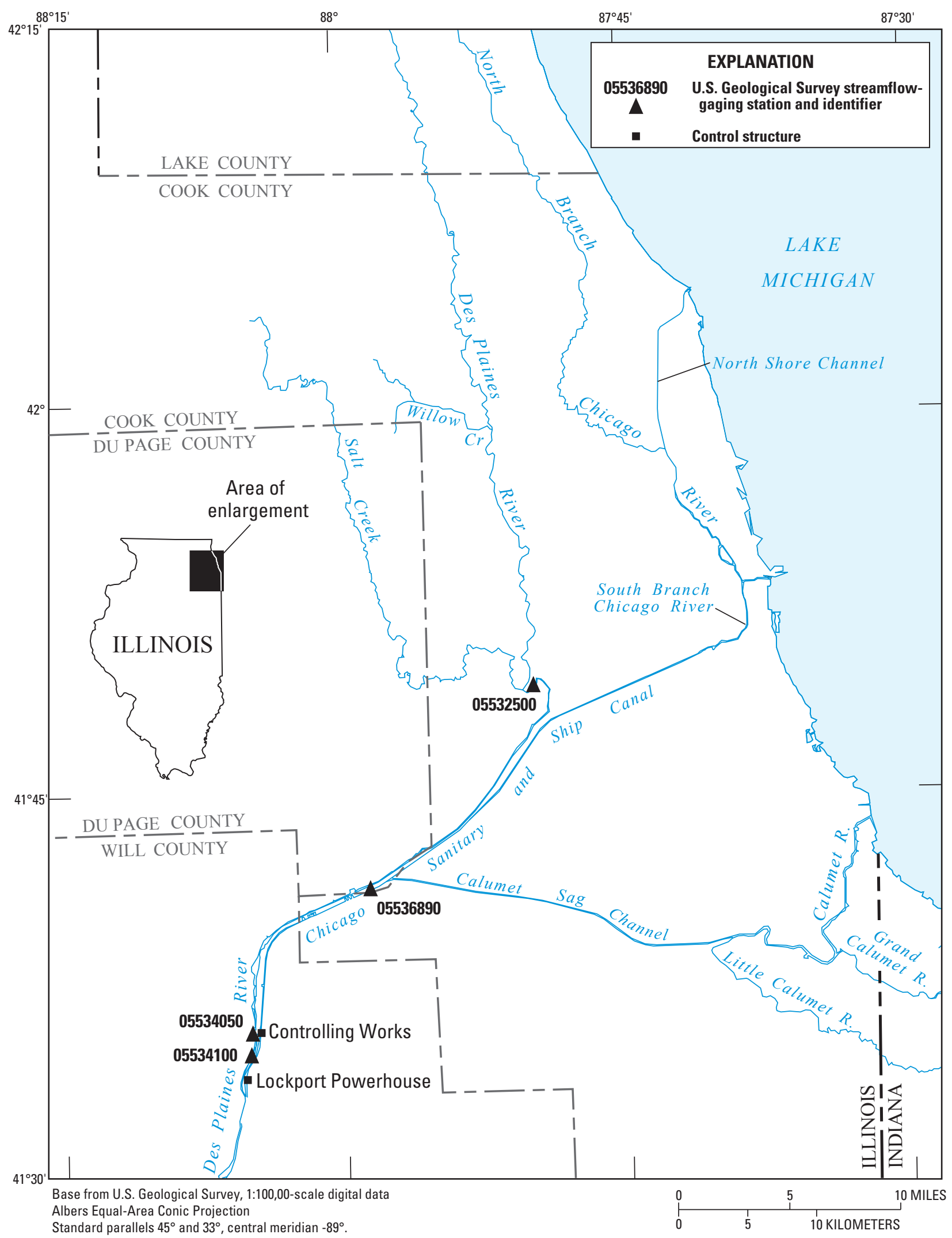

Figure 1. Location of the Lockport Powerhouse and Controlling Works and overview of drainage into the Chicago Sanitary and Ship Canal and Des Plaines River, Illinois. 
Table 1. Statistical summary of streamflow for the U.S. Geological Survey streamflow-gaging station on the Des Plaines River at Riverside, Illinois (05532500).

$\left[\mathrm{ft}^{3} / \mathrm{s}\right.$, cubic foot per second]

\begin{tabular}{|c|c|c|c|c|c|c|c|}
\hline \multirow{3}{*}{$\begin{array}{c}\text { Water } \\
\text { year }(\mathbf{s})^{1}\end{array}$} & \multirow{3}{*}{$\begin{array}{c}\text { Annual } \\
\text { mean } \\
\text { streamflow } \\
\left(\mathrm{ft}^{3} / \mathbf{s}\right)\end{array}$} & \multicolumn{4}{|c|}{ Daily mean streamflow } & \multirow{2}{*}{\multicolumn{2}{|c|}{$\begin{array}{c}\text { Maximum } \\
\text { peak streamflow }\end{array}$}} \\
\hline & & \multicolumn{2}{|c|}{ Highest } & \multicolumn{2}{|c|}{ Lowest } & & \\
\hline & & $\begin{array}{c}\text { Streamflow } \\
\left(\mathrm{ft}^{3} / \mathrm{s}\right)\end{array}$ & Date & $\begin{array}{c}\text { Streamflow } \\
\left(\mathrm{ft}^{3} / \mathrm{s}\right)\end{array}$ & Date & $\begin{array}{c}\text { Streamflow } \\
\left(\mathrm{ft}^{3} / \mathrm{s}\right)\end{array}$ & Date \\
\hline 2010 & 942 & 6,720 & $07 / 25 / 2010$ & 180 & 09/30/2010 & 8,380 & $07 / 24 / 2010$ \\
\hline 1944-2010 & 589 & 9,180 & $08 / 15 / 1987$ & 0 & 08/23/1962 & 9,770 & $08 / 15 / 1987$ \\
\hline
\end{tabular}

${ }^{1} \mathrm{~A}$ water year (WY) is the 12-month period from October 1 through September 30 and is designated by the calendar year in which it ends. For example, WY 2010 is from October 1, 2009, to September 30, 2010.

\section{Previous Studies}

The earliest record found of structure ratings near Lockport, Illinois, was a paper copy of a controlling works rating table dated 1947 (Phil Nieman, Metropolitan Water Reclamation District of Greater Chicago, written commun., 2010). In 1961, a University of Illinois Master's Thesis was completed utilizing a physical model to study the flow conditions at the Lockport Powerhouse (Muga, 1961). In 1985, the USACE analyzed and revised ratings based on theory and previous studies for both the powerhouse and controlling works (Hart and McGee, 1985).

\section{Lockport Controlling Works}

The Lockport Controlling Works (LCW) is located $2.1 \mathrm{mi}$ upstream of the Lockport Lock and Powerhouse (fig. 1). The drainage area at the headwater gage (CSSC at Lockport Controlling Works (CSSC-LCW), Illinois, 05536998) is $739.5 \mathrm{mi}^{2}$. The structure is used to divert water from the CSSC into the Des Plaines River. The structure consists of seven $30-\mathrm{ft}$ wide sluice gates with a sill elevation of -15.0 Chicago City Datum (CCD) (figs. 2-7).

\section{Approach}

To determine flow through the LCW, two streamgages were installed in March 2010 on the Des Plaines River at Lockport (DPR-L), Illinois (05534050), and Des Plaines River at Division Street at Lockport (DPR-DSL), Illinois (05534100). Both gages had continuous stage sensors (collected at 5-minute interval), as well as storm event measurements and routine flow measurements, made as needed for rating development and continuous-discharge calculation. The DPR-L gage (05534050) was located on the Materials Road bridge immediately upstream of where the controlling works flow enters the Des Plaines River (figs. 2 and 3). This location included an acoustic side-looker measurement device which provided velocity data for a velocity-index rating (Ruhl and Simpson, 2005; Morlock and others, 2002) because of the backwater effect from the controlling-works flow that precluded use of a standard stage-discharge rating to obtain accurate discharge data.

The DPR-DSL gage was located on the Division Street bridge (fig. 2) downstream of where the controlling works flow enters the Des Plaines River. The 9th Street bridge was considered as a possible location, but rejected because of observed turbulent and air-entrained high flow conditions that would make ADCP measurements difficult and less accurate. A bank-operated cableway was installed to help facilitate ADCP measurements at Division Street. The difference in flow between the gages DPR-L and DPR-DSL was used as the flow through the controlling works.

Two stage sensors were installed at the CSSC headwater gage (05536998) near the controlling works (fig. 3). The base gage at CSSC-LCW was on the south side of the controlling works and the auxiliary gage was as far north on the old structure as possible to be out of the drawdown, but still not in the vicinity of docking barges (sensor located approximately $300 \mathrm{ft}$ upstream of the first gate as shown in fig. 3). Most hydraulic formulae to compute discharge are based on the head outside of the drawdown zone. Under current (2012) MWRD operating conditions, the canal is lowered significantly using the powerhouse, and consequently, rapid drawdown does not occur at the controlling works. For the purposes of this study, only the base gage was used because the streambed is exposed at approximately $-8.5 \mathrm{ft} \mathrm{CCD}$ at the auxiliary gage, preventing data collection within the operating conditions of the canal.

Data from MWRD headwater and tailwater gages (fig. 3) were not recoverable for the study period and could not be used to compute submergence ratios. Submergence ratios were instead calculated using data from CSSC-LCW and DPR-L. The submergence ratios are needed to determine which rating equation should be used. The structure rating development used a range of canal stages, along with standard control-structure rating techniques (Chow, 1959; Collins, 1977; Roberson and others, 1998). 


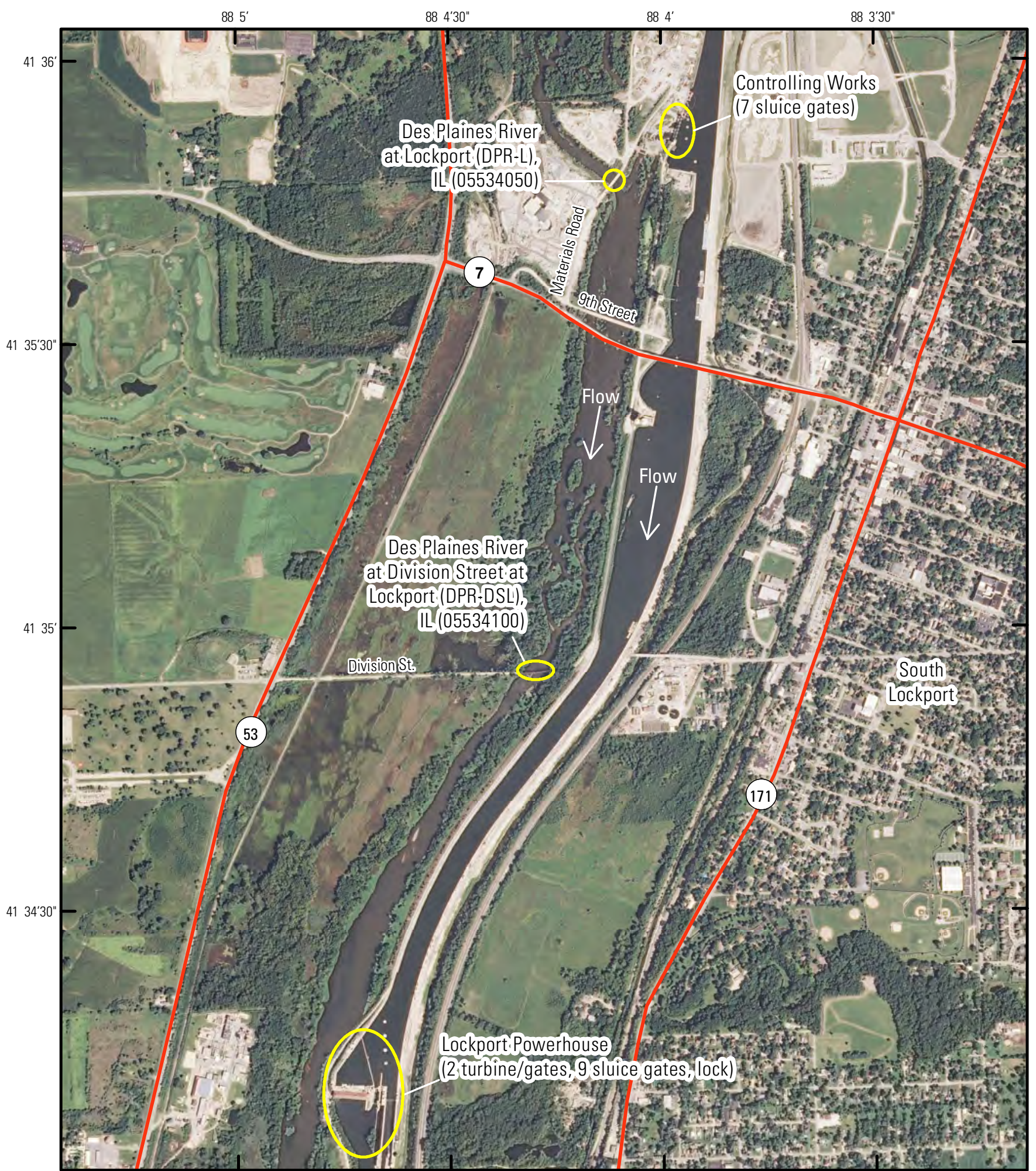

Imagery from U.S. Department of Agriculture, Farm Service Agency, National Agriculture Imagery Program (NAIP) for Illinois, 2011.

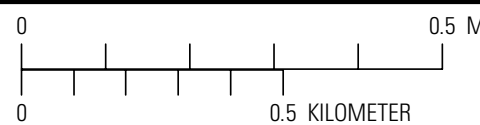

Figure 2. Aerial image of the Lockport Powerhouse, Controlling Works, and Des Plaines River, Illinois, streamgages used to determine flow through the Lockport Controlling Works. 


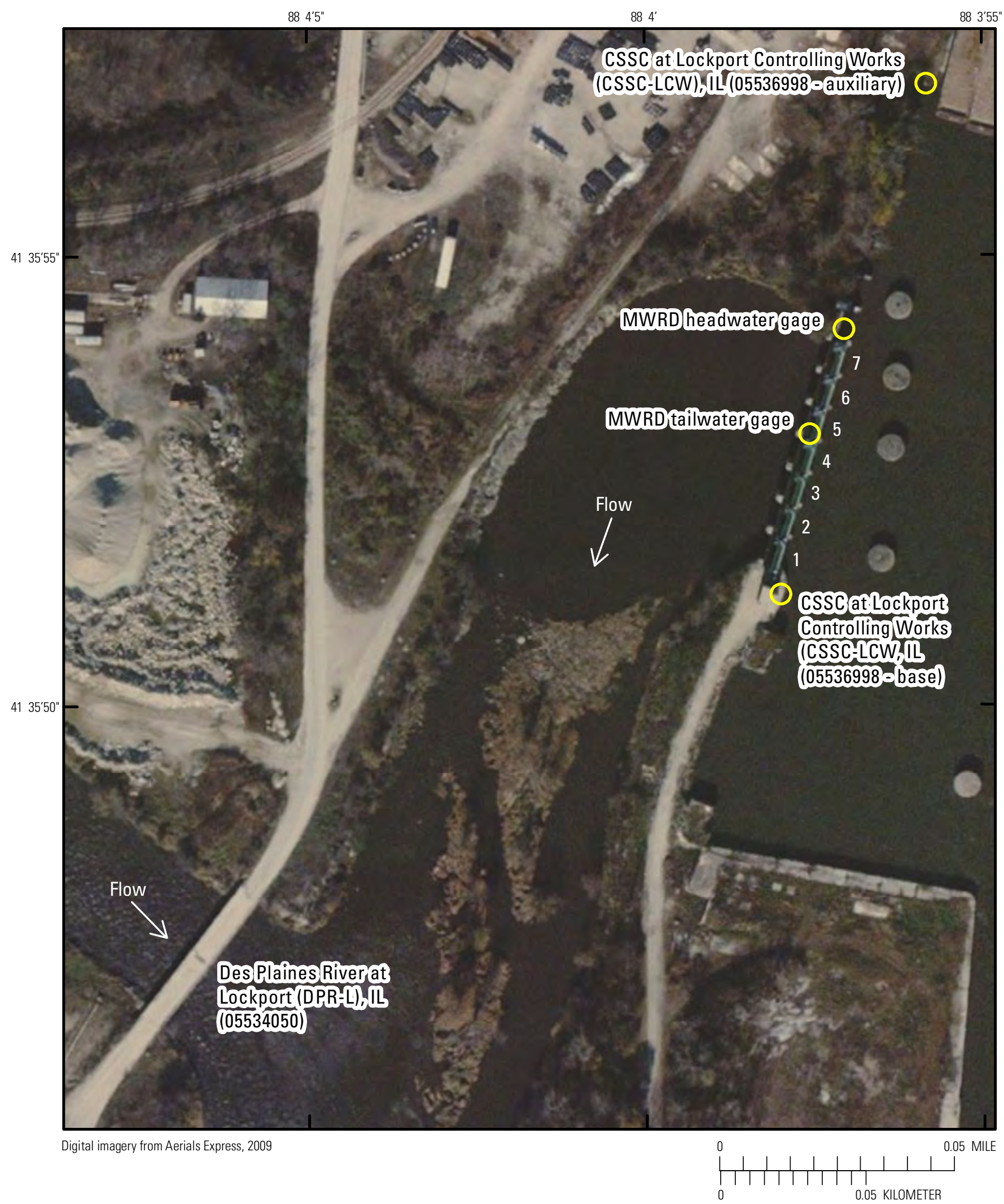

Figure 3. Aerial image of the Lockport Controlling Works and headwater gages and Des Plaines River at Lockport, Illinois, streamgage. [CSSC, Chicago Sanitary and Ship Canal; MWRD, Metropolitan Water Reclamation District; USACE, U.S. Army Corps of Engineers] 


\section{Measurement Summary}

To develop a rating for the Lockport Controlling Works, streamflow, velocity, and stage data were collected on the Des Plaines River and CSSC during March-November 2010 at the following locations (figs. 2 and 3):

- Des Plaines River at Lockport (DPR-L) (05534050)

- Location: Upstream of the controlling-works diverted flow

- Data: Continuous stage, index velocity, and streamflow

- Des Plaines River at Division Street at Lockport (DPR-DSL) (05534100)

- Location: Downstream of the controlling-works diverted flow

- Data: Continuous stage and streamflow

- Chicago Sanitary and Ship Canal at Lockport Controlling Works (CSSC-LCW) (05536998)

- Location: Headwater elevations for the controlling works

- Data: Continuous stage

The continuous-stage and streamflow data are stored in the USGS National Water Information System (NWIS) database, and the daily mean values are available from the USGS Illinois Water Science Center Web site (http://il.water.usgs.gov). The discrete measurements for the Des Plaines River gages are presented in tables 2 and 3. During an approximately 6-month period, there were 9 measurements ranging from 652 to $6,040 \mathrm{ft}^{3} / \mathrm{s}$ at DPR-L, and 10 measurements ranging from 220 to $10,800 \mathrm{ft}^{3} / \mathrm{s}$ at DPR-DSL. Generally the number of transects ranged from four to eight per standard USGS methods (Turnipseed and Sauer, 2010). Eight are used if the original four are not within a specified percentage of each other. Other factors also contributed to the measurement time of these including the bank operated cableway, fenderwall setup, hydraulic conditions, and weather conditions. Stream conditions near DPR-L and CSSC-LCW during two storm events when the controlling works were in operation are shown in figures 5 and 6.
Table 2. Streamflow measurements during the study period for the U.S. Geological Survey streamflow-gaging station at Des Plaines River at Lockport (DPR-L), Illinois (05534050).

$\left[\mathrm{ft}^{3} / \mathrm{s}\right.$, cubic foot per second]

\begin{tabular}{ccccc}
\hline \multirow{2}{*}{$\begin{array}{c}\text { Measurement } \\
\text { number }\end{array}$} & Date & \multicolumn{2}{c}{ Time } & $\begin{array}{c}\text { Measured } \\
\text { streamflow } \\
\text { (ft } \mathbf{3} / \mathbf{s})\end{array}$ \\
\cline { 3 - 4 } & & Start & End & 3,680 \\
\hline 94 & $03 / 16 / 10$ & $14: 01$ & $14: 20$ & 2,780 \\
95 & $04 / 08 / 10$ & $09: 05$ & $09: 19$ & 1,130 \\
96 & $04 / 16 / 10$ & $07: 43$ & $09: 00$ & 2,090 \\
97 & $05 / 13 / 10$ & $10: 25$ & $10: 56$ & 2,210 \\
\hline 99 & $05 / 13 / 10$ & $16: 30$ & $16: 54$ & 1,090 \\
\hline 100 & $06 / 16 / 10$ & $14: 43$ & $15: 41$ & 3,250 \\
\hline 101 & $07 / 24 / 10$ & $18: 39$ & $19: 02$ & 6,040 \\
\hline 102 & $07 / 26 / 10$ & $11: 22$ & $11: 55$ & 652 \\
\hline
\end{tabular}

Table 3. Streamflow measurements during the study period for the U.S. Geological Survey streamflow-gaging station at Des Plaines River at Division Street at Lockport (DPR-DSL), Illinois (05534100).

$\left[\mathrm{ft}^{3} / \mathrm{s}\right.$, cubic foot per second]

\begin{tabular}{ccccc}
\hline \multirow{2}{*}{$\begin{array}{c}\text { Measurement } \\
\text { number }\end{array}$} & Date & \multicolumn{2}{c}{ Time } & $\begin{array}{c}\text { Measured } \\
\text { streamflow } \\
\text { (ft } \mathbf{s} \text { s) }\end{array}$ \\
\cline { 3 - 4 } & $4 / 16 / 2010$ & $7: 59$ & $8: 05$ & 1,250 \\
\hline 2 & $4 / 16 / 2010$ & $8: 05$ & $8: 45$ & 2,040 \\
\hline 4 & $4 / 16 / 2010$ & $9: 05$ & $9: 33$ & 2,330 \\
\hline 5 & $4 / 16 / 2010$ & $9: 33$ & $10: 01$ & 1,610 \\
\hline 6 & $5 / 13 / 2010$ & $12: 27$ & $13: 00$ & 5,940 \\
\hline 7 & $5 / 14 / 2010$ & $12: 48$ & $13: 07$ & 3,680 \\
\hline 8 & $7 / 24 / 2010$ & $20: 14$ & $20: 26$ & 10,800 \\
\hline 9 & $7 / 26 / 2010$ & $9: 48$ & $10: 13$ & 6,140 \\
10 & $8 / 23 / 2010$ & $17: 15$ & $18: 24$ & 652 \\
\hline 11 & $10 / 6 / 2010$ & $9: 41$ & $10: 42$ & 220 \\
\hline
\end{tabular}



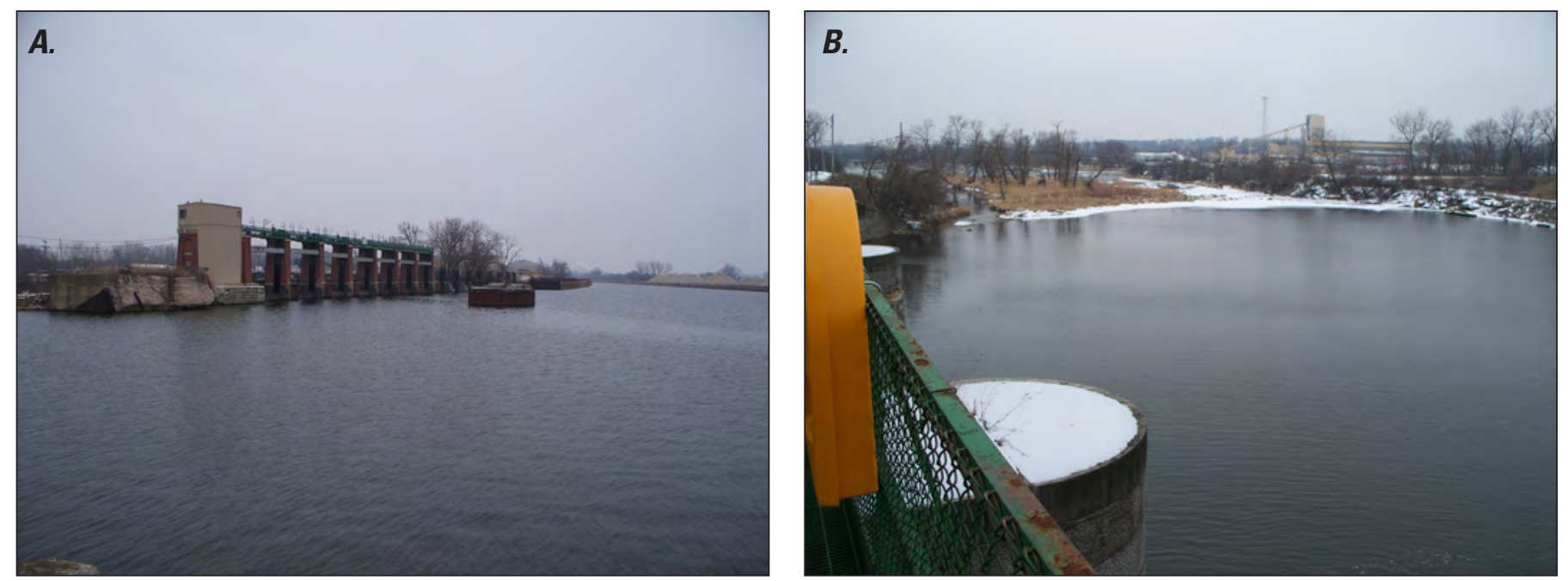

Figure 4. Photographs showing $A$, view looking upstream on the ship canal at the controlling works with all gates closed; and $B$, view looking downstream from the structure toward the Des Plaines River, Illinois.
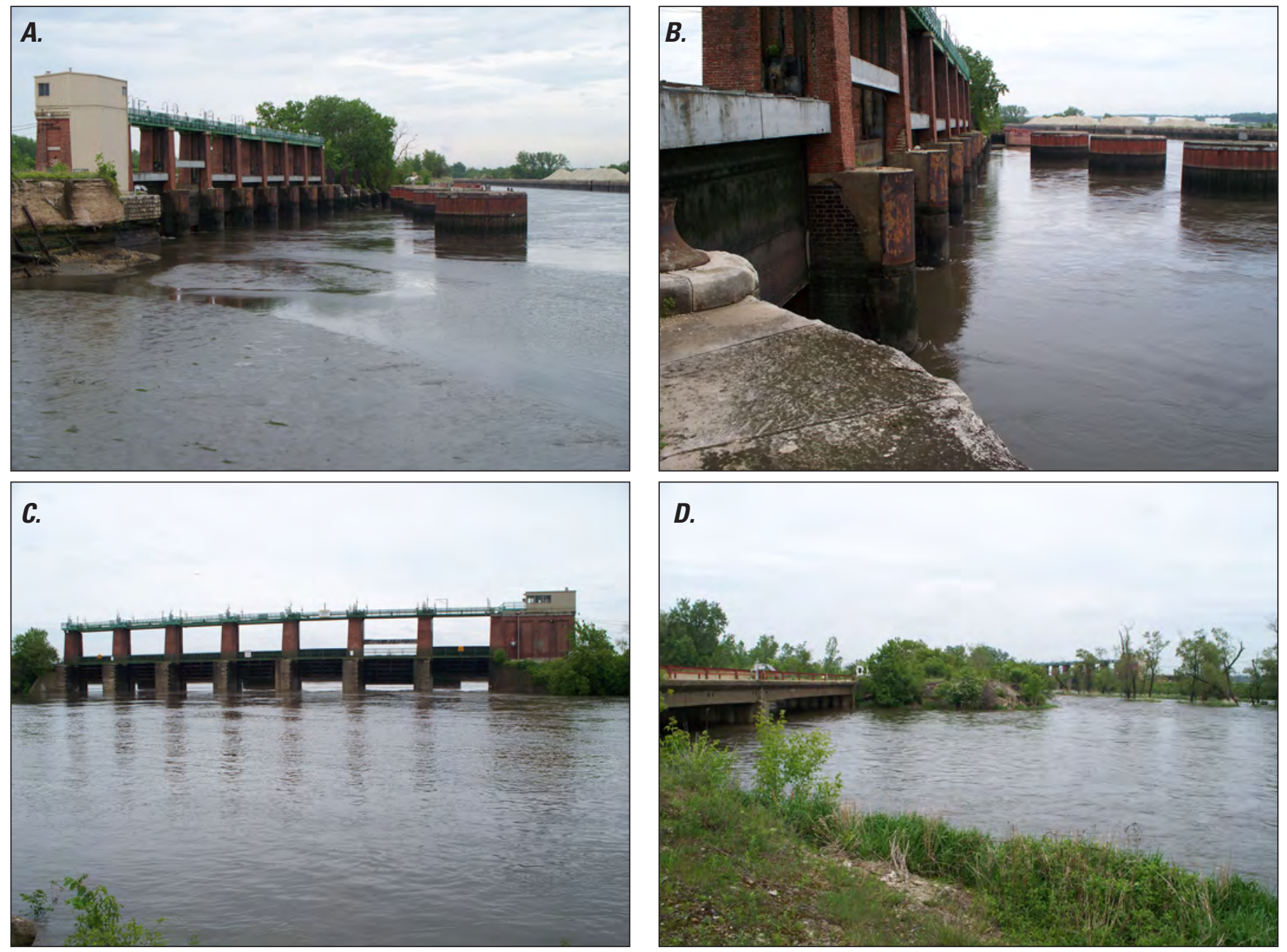

Figure 5. Photographs showing controlling works with all seven gates open on May 13, 2010, between 11:00 and 12:00 CST. $A$ and $B$, view looking upstream on the ship canal at the controlling works headwater conditions. $C$, view at the downstream side of the controlling works. $D$, view looking upstream at the Des Plaines River at Lockport, Illinois, streamgage (05534050) with downstream side of controlling works in the distance. 

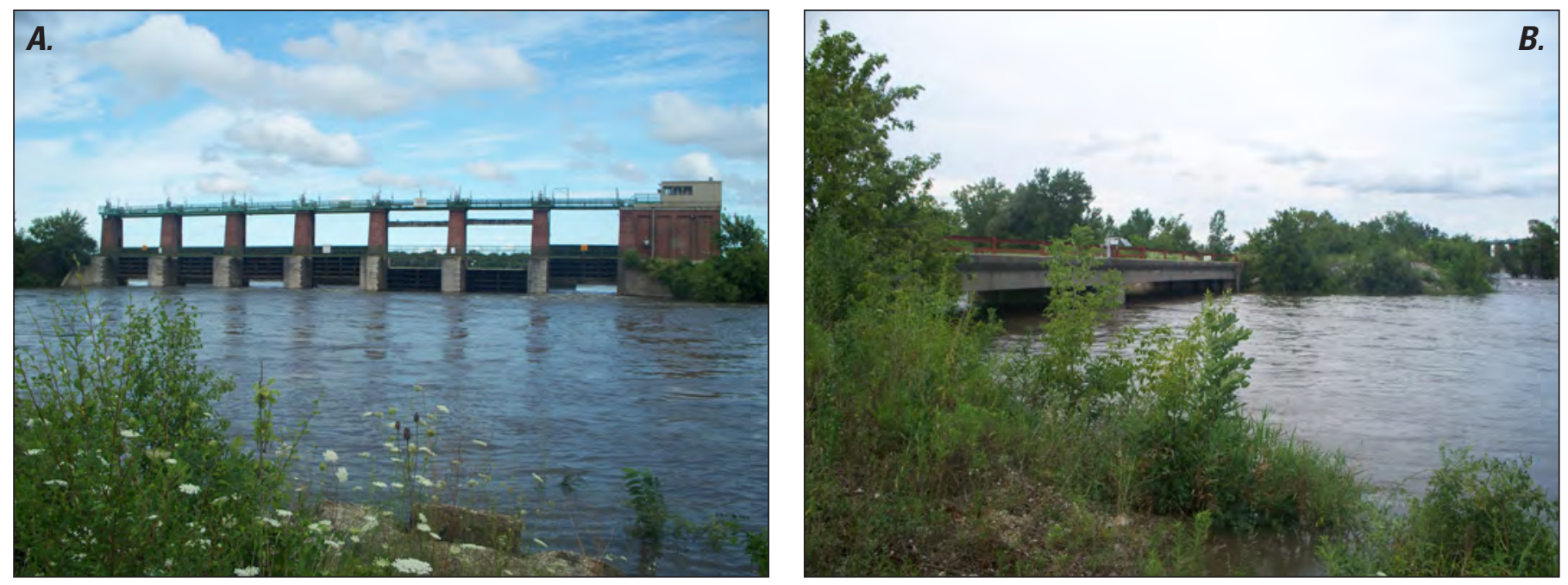

Figure 6. Controlling works with five gates open on July 24, 2010, at approximately 15:00 CST. $A$, view of the downstream side of the controlling works. $B$, view looking upstream at the Des Plaines River at Lockport, Illinois, streamgage (05534050) with downstream side of controlling works in the distance.

\section{Results}

Current (2012) flood-control operational procedure by MWRD includes initially lowering the water-surface elevation (WSE) in the canal using the powerhouse. The use of the powerhouse limits the effective reductions; therefore, during the two storm events (May 13 and July 24-25, 2010) measured in this study when the controlling works were in operation, the canal WSE ranged from -7.0 to $-10.5 \mathrm{ft} \mathrm{CCD}$ during the stable flow periods (table 4). For the new rating equations presented in this section, anything above a canal WSE of $-7.0 \mathrm{ft}$ is outside the range measured in this study, and more importantly, appears to be outside the range of the previously developed ratings. During the May event, all seven gates were open; during the July event, five gates were open (gates 1, 4, 5, 6, and 7; see fig. 3 for gate locations). Also, for the data used in equation development, the tailwater (DPR-L) to headwater
(CSSC-LCW-Base) ratios ranged from 0.44 to 0.46 and 0.31 to 0.66 in the May and July events, respectively.

A side-view schematic of the sluice gates and parameters used in the control-structure rating are shown in figure 7. The "measured" flow through the controlling works $\left(\mathrm{Q}_{\mathrm{CW}}\right)$ used for equation development was determined by subtracting the flow at DPR-L $\left(Q_{D P R-L}\right)$ from DPR-DSL $\left(Q_{D P R-D S L}\right)$ (in other words, $Q_{C W}=Q_{D P R-D S L}-Q_{D P R-\mathrm{L}}$. Forty and 491 flow values were used to describe free- and submerged-weir flow through the sluice gates, respectively. Conditions of the flow are listed in table 4 . Only stable flow conditions were used for equation development. Standard weir equations described in Chow (1959), Collins (1977), and Roberson and others (1998) are used in this report to describe flow through the sluice gates. Orifice flow conditions are not observed at the controlling works because the standard operation is to lift the gates completely out of the water. 
Table 4. Number of gates open and flow conditions for two storm events when the controlling works at Lockport, lllinois, were in operation.

\begin{tabular}{|c|c|c|c|c|c|c|}
\hline \multirow[b]{2}{*}{ Event } & \multirow{2}{*}{$\begin{array}{c}\text { Number of gates } \\
\text { open }\end{array}$} & \multirow{2}{*}{$\begin{array}{l}\text { Hours from first } \\
\text { gate open to last } \\
\text { gate closed }\end{array}$} & \multicolumn{4}{|c|}{ Flow conditions (hours) } \\
\hline & & & $\begin{array}{l}\text { Rapidly } \\
\text { changing }\end{array}$ & Stable & Free weir $^{1}$ & Submerged weir ${ }^{2}$ \\
\hline May 13, 2010 & 7 & 10.8 & 4.0 & 6.8 & 1.2 & 9.6 \\
\hline July 24-26, 2010 & 5 & 43.8 & 6.3 & 37.5 & 6.7 & 37.2 \\
\hline
\end{tabular}

${ }^{1}$ Free-weir equation developed using stable flow data from 03:20 to 06:35 on July 24, 2010.

${ }^{2}$ Submerged-weir equation developed using stable flow data from 06:50 to 13:30 on May 13, 2010, and 06:40 on July 24 to 16:45 on July 25,2010 .

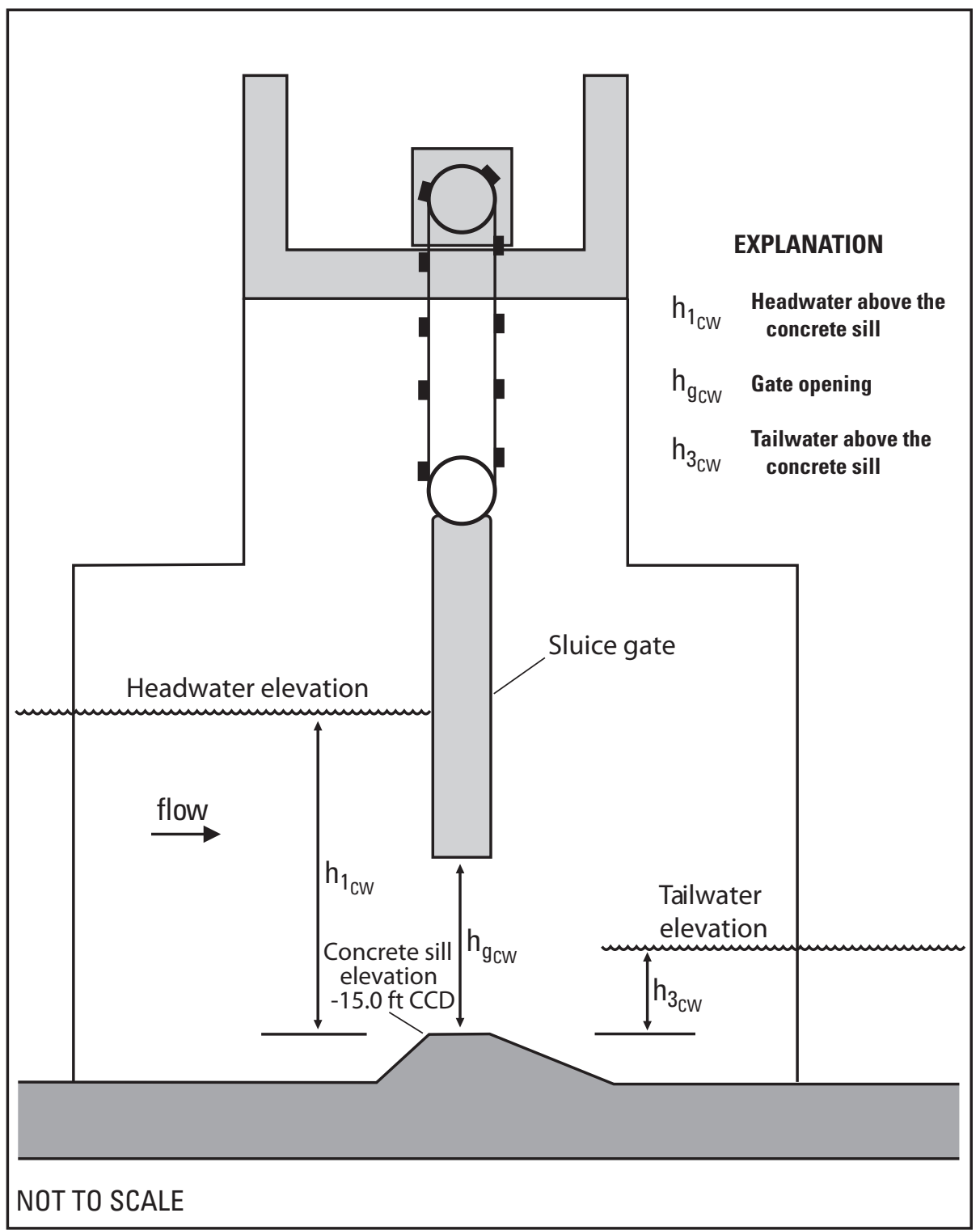

Figure 7. Schematic (side view) of the Controlling Works sluice gates on the Chicago Sanitary and Ship Canal at Lockport, Illinois. [ft, foot; CCD, Chicago City Datum] 
Utilizing the subtraction of the continuous-flow data from the gaging stations $\left(Q_{C W}=Q_{D P R-D S L}-Q_{D P R-L}\right)$, the resulting free- and submerged-weir equations are presented later in this section and in figure 8 . The measured $C_{C W}$ and $C_{C W-S}$ on the y-axis in figure 8 are obtained by using $Q_{C W}$ and measured headwater depth and calculating for the coefficients in equations 2 and 8. The data indicate the following flow-regime criteria conditions. Free-weir flow occurs when $h_{3_{C W}} / h_{1_{C W}}$ is less than or equal to 0.37 . These data are shown in figure
$8 A$ and correspond to higher coefficients as compared to the submerged data (fig. $8 B$ ) for the same headwater depths.

Submerged-weir flow occurs when $h_{3_{C W}} / h_{1}$ is greater than 0.37 . The value of 0.37 is lower than traditional submergence criteria because of the proximity of the tailwater measurement at DPR-L, which is further downstream than a traditional tailwater gage (fig. 3). Hart and McGee (1985) recommend a tailwater gage location approximately $50 \mathrm{ft}$ due west of the current (2012) MWRD tailwater gage (fig. 3).

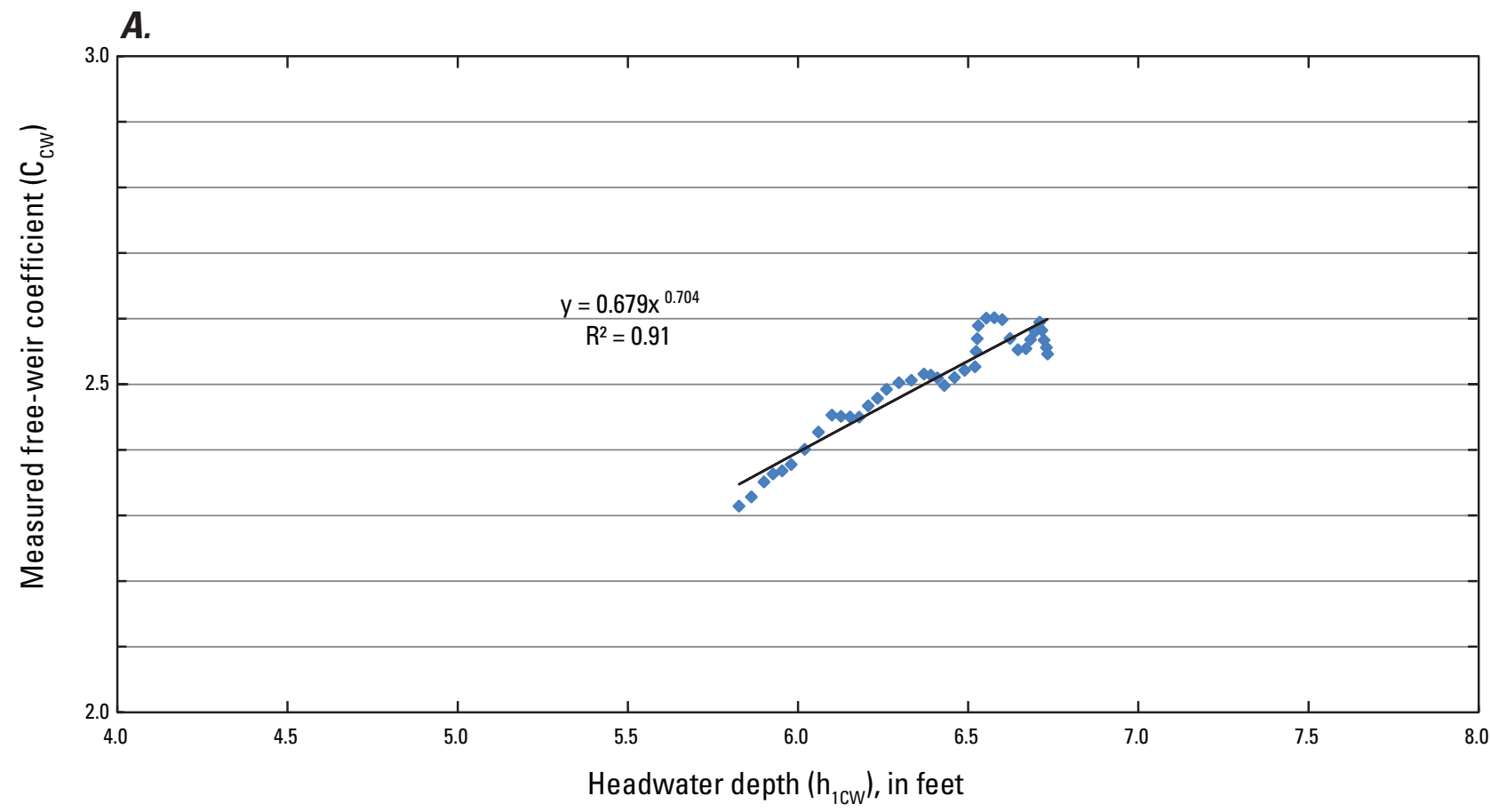

B.

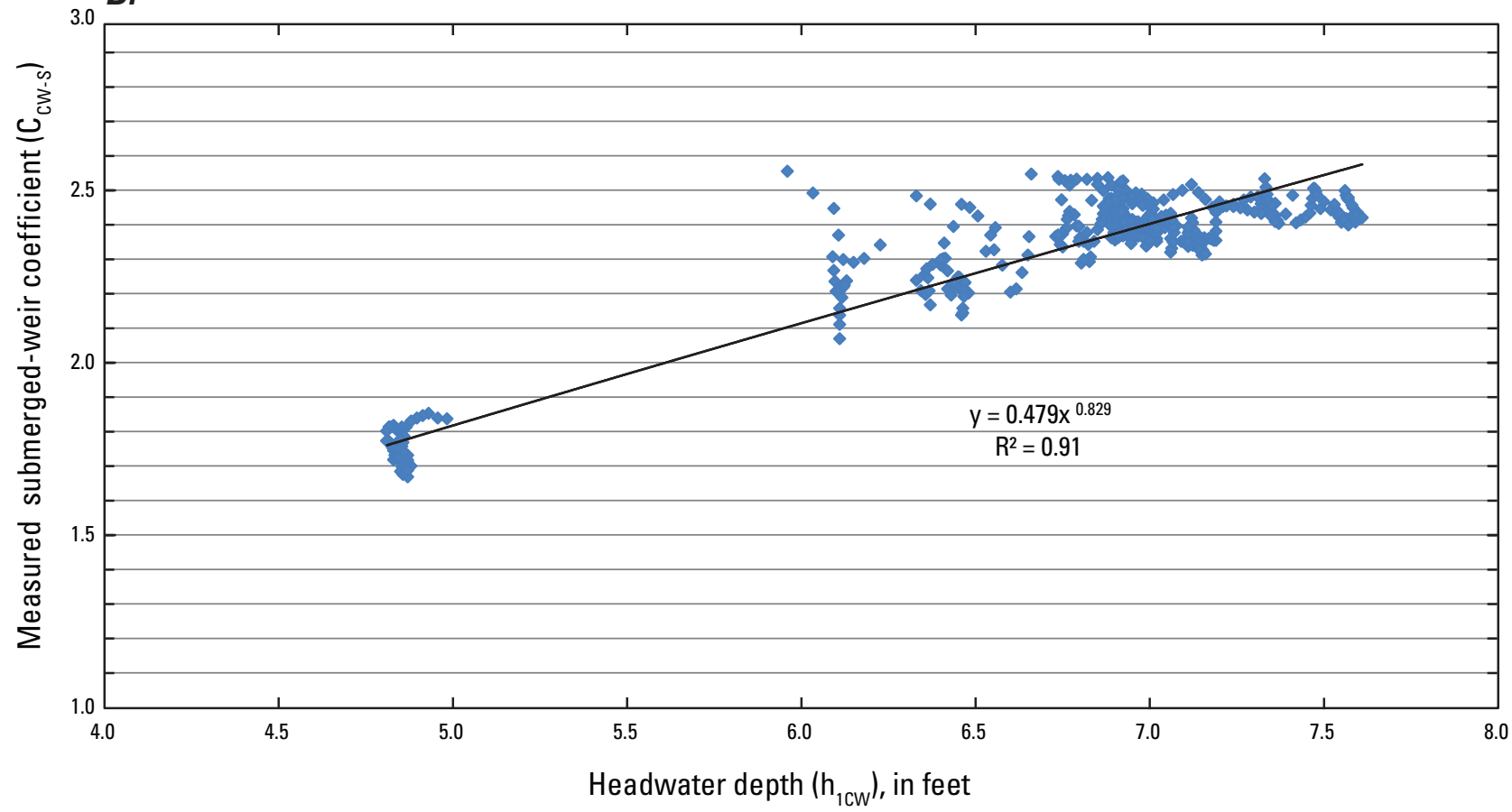

Figure 8. Discharge coefficient for A, free-weir flow and B, submerged-weir flow, and the headwater depth for the controlling works sluice gates on the Chicago Sanitary and Ship Canal near Lockport, Illinois. [ ${ }^{2}$, coefficient of determination] 
Free-weir (FW) flow occurs when

$$
\frac{h_{3_{C W}}}{h_{1_{C W}}} \leq 0.37
$$

FW flow equations developed for canal headwater elevations $\left(\mathrm{HW}_{\mathrm{CW}}\right)$ ranging from -7.0 to $-10.5 \mathrm{ft} \mathrm{CCD}$

$$
\begin{gathered}
Q_{C W}=C_{C W} B_{C W} h_{1_{C W}^{1.5}}^{1.5} \\
C_{C W}=0.679 h_{1_{C W}^{0.704}}^{0.6} \\
h_{1_{C W}}=H W_{C W}+15 f t \\
B_{C W}=N_{C W} \times 30 f t=30 N_{C W} \\
Q_{C W}=20.37 N_{C W}\left(H W_{C W}+15\right)^{2.204}
\end{gathered}
$$

where

$h_{3_{C W}} \quad$ is tailwater depth above the sluice-gate sill, in $\mathrm{ft}$ (measured at gage DPR-L);

$h_{1_{C W}} \quad$ is headwater depth above the sluice-gate sill, in $\mathrm{ft}$ (measured at gage CSSC-LCW);

$Q_{C W} \quad$ is flow through the controlling works, in $\mathrm{ft}^{3} / \mathrm{s}$;

$C_{C W}$ is free-weir coefficient for the sluice gates;

$H W_{C W} \quad$ is canal headwater elevation near the controlling works in $\mathrm{CCD}$, in $\mathrm{ft}$;

$B_{C W} \quad$ is length of gates, in $\mathrm{ft}$; and

$N_{C W} \quad$ is number of gates open.

Submerged-weir (SW) flow occurs when

$$
\frac{h_{3_{C W}}}{h_{1_{C W}}}>0.37
$$

SW flow equations developed for canal headwater elevations $\left(\mathrm{HW}_{\mathrm{CW}}\right)$ ranging from -7.0 to $-10.5 \mathrm{ft} \mathrm{CCD}$

$$
Q_{C W}=C_{C W-S} B_{C W} h_{1_{C W}}^{1.5}
$$

$$
C_{C W-S}=0.479 h_{1_{C W}^{0.829}}^{0.9}
$$

$$
h_{1_{C W}}=H W_{C W}+15 f t
$$

$$
B_{C W}=N_{C W} \times 30 f t=30 N_{C W}
$$

$$
Q_{C W}=14.37 N_{C W}\left(H W_{C W}+15\right)^{2.329}
$$

where

$$
\begin{aligned}
& h_{3_{C W}} \quad \text { is tailwater depth above the sluice-gate sill, in } \\
& \mathrm{ft} \text { (measured at gage DPR-L); } \\
& h_{1_{C W}} \quad \text { is headwater depth above the sluice-gate sill, } \\
& Q_{C W} \quad \text { in } \mathrm{ft} \text { (measured at gage CSSC-LCW); } \\
& \text { is flow through the controlling works, in } \mathrm{ft}^{3} / \mathrm{s} \text {; } \\
& C_{C W-S} \text { is submerged-weir coefficient for the sluice } \\
& \text { gates; } \\
& H W_{C W} \quad \text { is canal headwater elevation near the } \\
& B_{C W} \quad \text { controlling works in CCD, in } \mathrm{ft} \text {; } \\
& B_{C W} \quad \text { is length of gates, in } \mathrm{ft} \text {; and } \\
& N_{C W} \quad \text { is number of gates open. }
\end{aligned}
$$

The discrete measured and computed sluice-gate flows for the controlling works are presented, for comparison, in figure 9 . Of the 531 computed sluice-gate flow values, all but 3 are within 10 percent of measured flows. The slope of weir coefficient and headwater depth relation appears to be leveling off for headwater depths above $7.5 \mathrm{ft}$ (equals headwater elevations greater than $-7.5 \mathrm{ft} \mathrm{CCD}$ ) (fig. 8). Measurements at higher headwater depths are needed to verify this preliminary observation. 


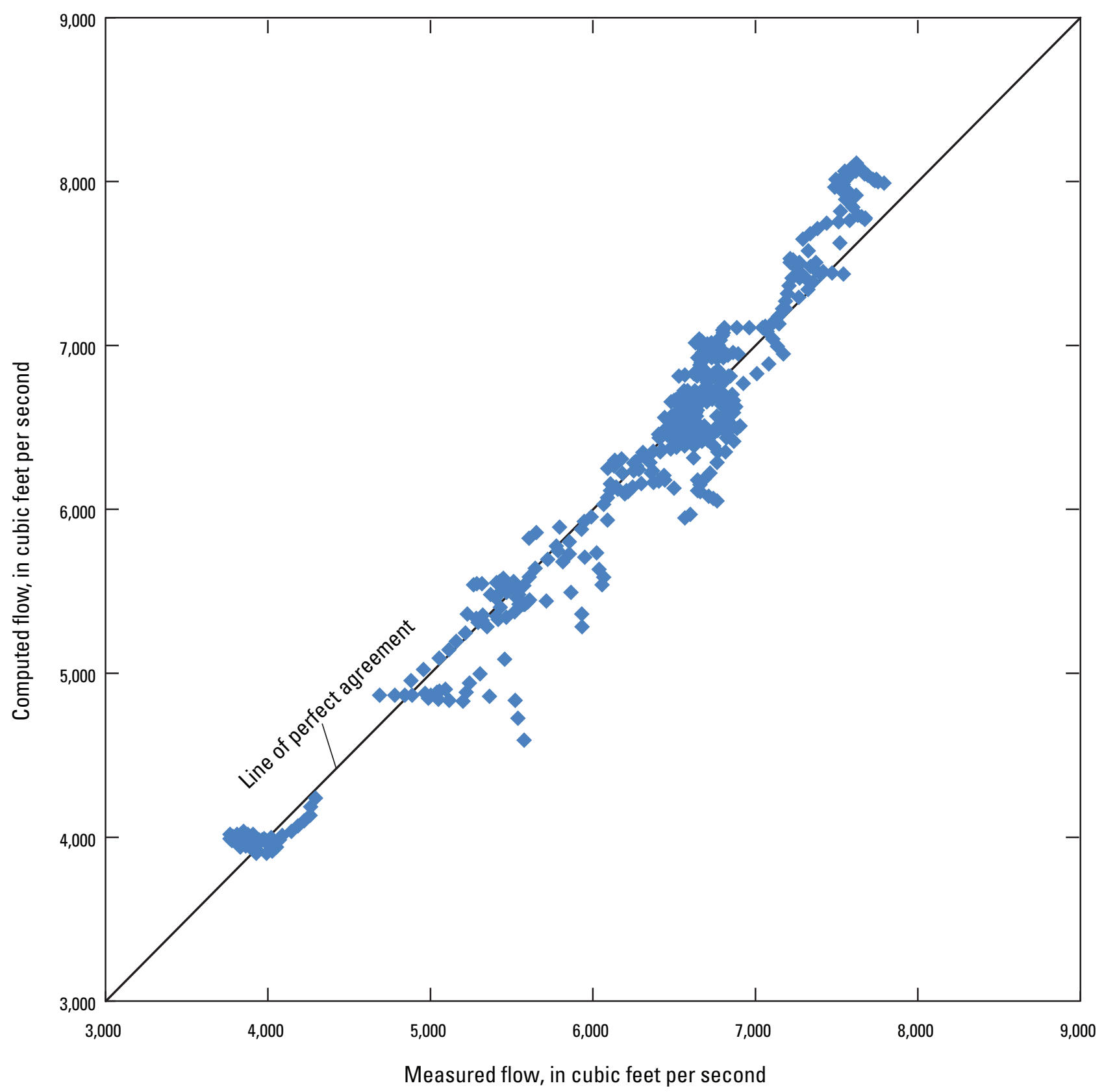

Figure 9. Comparison of continuous-flow data measured at U.S. Geological Survey streamflow-gaging stations and flow computed using the 2011 equations for the controlling works sluice gates on the Chicago Sanitary and Ship Canal near Lockport, Illinois.

Flow ratings for the controlling works sluice gate from 1947,1985 , and 2011 are shown in figure 10. Note that the 2011 ratings (developed in this study) should be used only for headwater elevations ranging from -7.0 to $-10.5 \mathrm{ft} \mathrm{CCD}$, which is the elevation range of the data collected. Also, the 1985 study contains 46 pages of tables on how to adjust the rating for submergence based on tailwater, which are not represented in the rating on figure 10, but are discussed in reference to figure 11 .
Continuous-flow data at the controlling works on May 13,2010 , and July 24-25, 2010, and computed flow using the 1947, 1985, and 2011 methods are presented in figure 11. The 1947 method overpredicts flow through the gates. The 1985 method matches the measured flow well if a submergence adjustment is made. The MWRD tailwater data were not recoverable for these events, so various submergence adjustments were made until the 1985 method matched the measured flow. The adjustments were 35 and 18 percent 

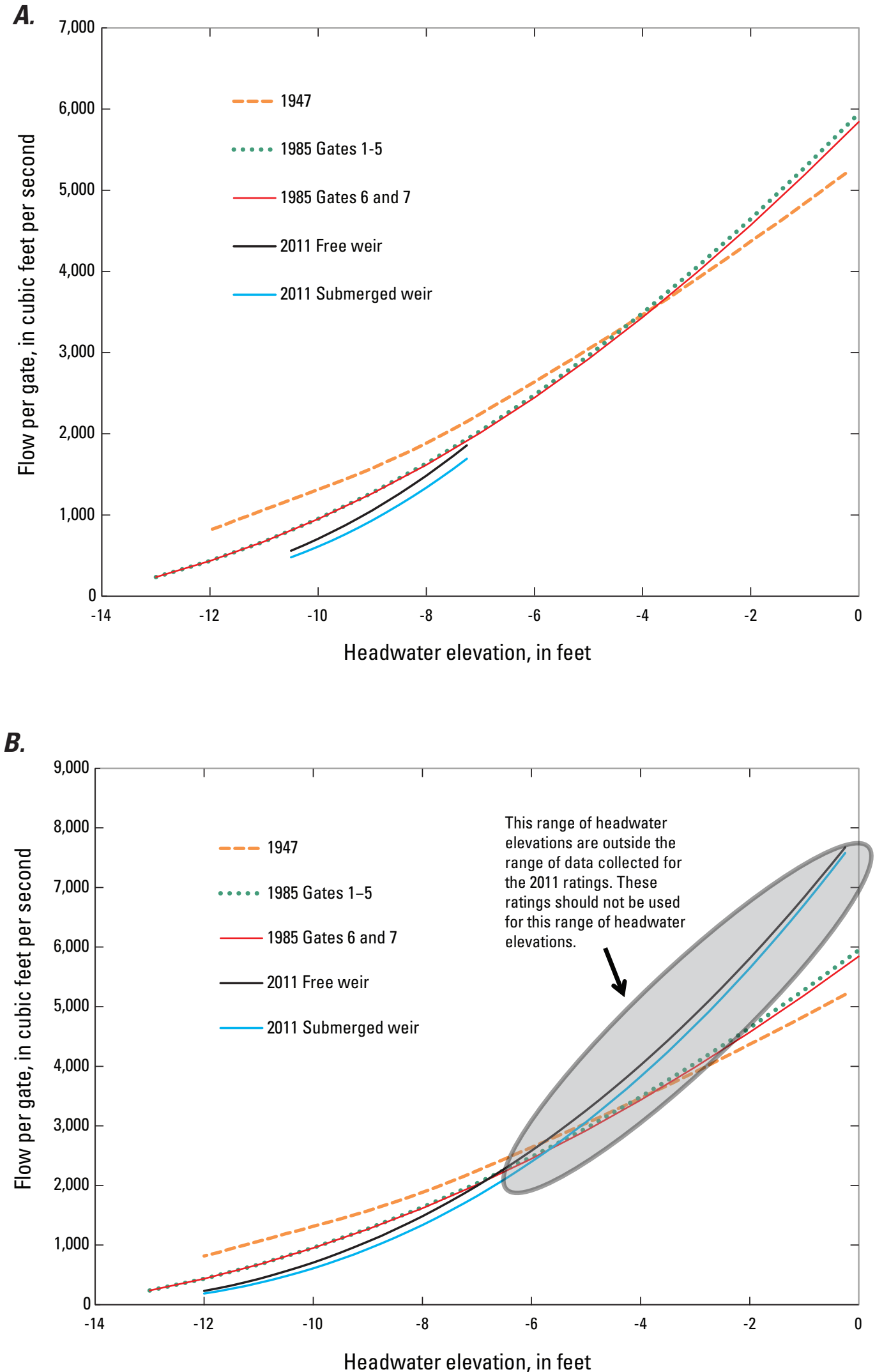

Figure 10. Flow per controlling works sluice gate and headwater elevation for 1947, 1985, and 2011 ratings and illustrating, $A$, the 2011 ratings should be used only for the headwater elevations ranging from -7.0 to -10.5 feet Chicago City Datum, which is the elevation range that the data were collected and, $B$, that use of 2011 ratings in the shaded zone above -7.0 feet might result in erroneous flow values. 

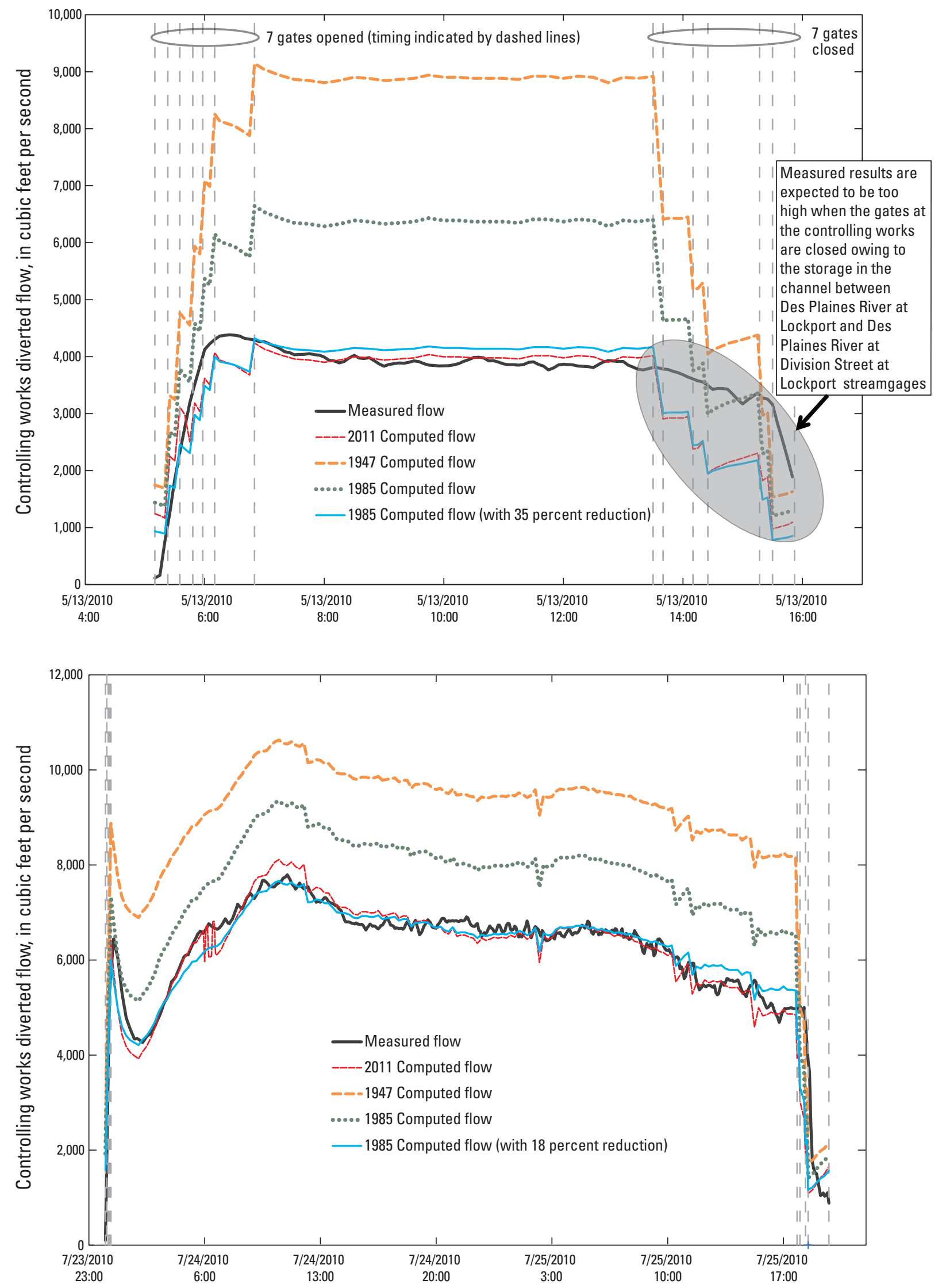

Figure 11. Controlling works continuous-flow data measured at U.S. Geological Survey streamflow-gaging stations and flow computed using 1947, 1985, and 2011 methods. 
reductions for the May and July events, respectively (both are within ranges found in Hart and McGee (1985)). However, the average submergence coefficients using the DPR-L gage (for the period of record used in the equation development) were 0.45 and 0.55 for the May and July events, respectively. Given the reductions needed, the inverse of the submergence coefficients would be expected, but DPR-L was never intended for these purposes, and there is uncertainty in what is occurring between the water level at DPR-L and the controlling works. Lastly, owing to the storage in the channel between DPR-L and DPR-DSL, measured results are expected to be too high for all computed-flow methods when the gates at the controlling works are in the process of closing.

\section{Example Calculations}

\section{Example 1: Free-Weir Flow}

The following conditions exist:

Five gates are open

Headwater stage (measured at gage CSSC-LCW) $=$ $-9.02 \mathrm{ft}$

Tailwater stage (measured at gage DPR-L) $=-13.07 \mathrm{ft}$

In order to determine the flow regime for the current conditions, convert the stages to depths above the sluice-gate sill. The top of the sluice-gate sill is at $-15 \mathrm{ft} \mathrm{CCD}$. The headwater depth $\left(h_{1_{C W}}\right)$ and tailwater depth $\left(h_{3_{C W}}\right)$ are calculated by adding $15 \mathrm{ft}$ to the headwater and tailwater stages, respectively.

$$
\begin{gathered}
h_{1_{C W}}=-9.02+15=5.98 f t \\
h_{3_{C W}=}-13.07+15=1.93 f t \\
\frac{h_{3_{C W}}}{h_{1_{C W}}}=0.32
\end{gathered}
$$

Because $\frac{h_{3_{C W}}}{h_{1_{C W}}}$ is less than 0.37 , free-weir flow exists. Therefore, use equation 6 to calculate flow:

$$
\begin{gathered}
Q_{C W}=20.37 N_{C W}\left(H W_{C W}+15\right)^{2.204} \\
Q_{C W}=20.37 \times 5 \times(-9.02+15)^{2.204} \\
Q_{C W}=5,246 f t^{3} / s
\end{gathered}
$$

\section{Example 2: Submerged-Weir Flow}

The following conditions exist:

Seven gates are open

Headwater stage (measured at gage CSSC-LCW $)=$ $-10.16 \mathrm{ft}$

Tailwater stage (measured at gage DPR-L) $=-12.88 \mathrm{ft}$

In order to determine the flow regime for the current conditions, convert the stages to depths above the sluice-gate sill. The top of the sluice-gate sill is at $-15 \mathrm{ft}$ CCD. The headwater depth $\left(h_{1_{C W}}\right)$ and tailwater depth $\left(h_{3_{C W}}\right)$ are calculated by adding $15 \mathrm{ft}$ to the headwater and tailwater stages, respectively.

$$
\begin{aligned}
& h_{1_{C W}}=-10.16+15=4.84 f t \\
& h_{3_{C W}}=-12.88+15=2.12 f t
\end{aligned}
$$

Because $\frac{h_{3_{C W}}}{h_{1_{C W}}}$ is greater than 0.37 , submerged-weir flow exists. Therefore, use equation 12 to calculate flow:

$$
\begin{gathered}
Q_{C W}=14.37 N_{C W}\left(H W_{C W}+15\right)^{2.329} \\
Q_{C W}=14.37 \times 7 \times(-10.16+15)^{2.329} \\
Q_{C W}=3,959 \mathrm{ft}^{3} / \mathrm{s}
\end{gathered}
$$

\section{Lockport Powerhouse}

The Lockport Powerhouse is located adjacent to the Lockport Lock (fig. 12). The drainage area at the headwater gage (CSSC at Lockport Powerhouse (CSSC-LPH), Illinois, 05537000 ) is $740 \mathrm{mi}^{2}$. The structure consists of nine 9-ft wide by $14-\mathrm{ft}$ high sluice gates with a sill elevation of $-28.42 \mathrm{CCD}$ and two 10-ft diameter turbines (figs. 12-15). 


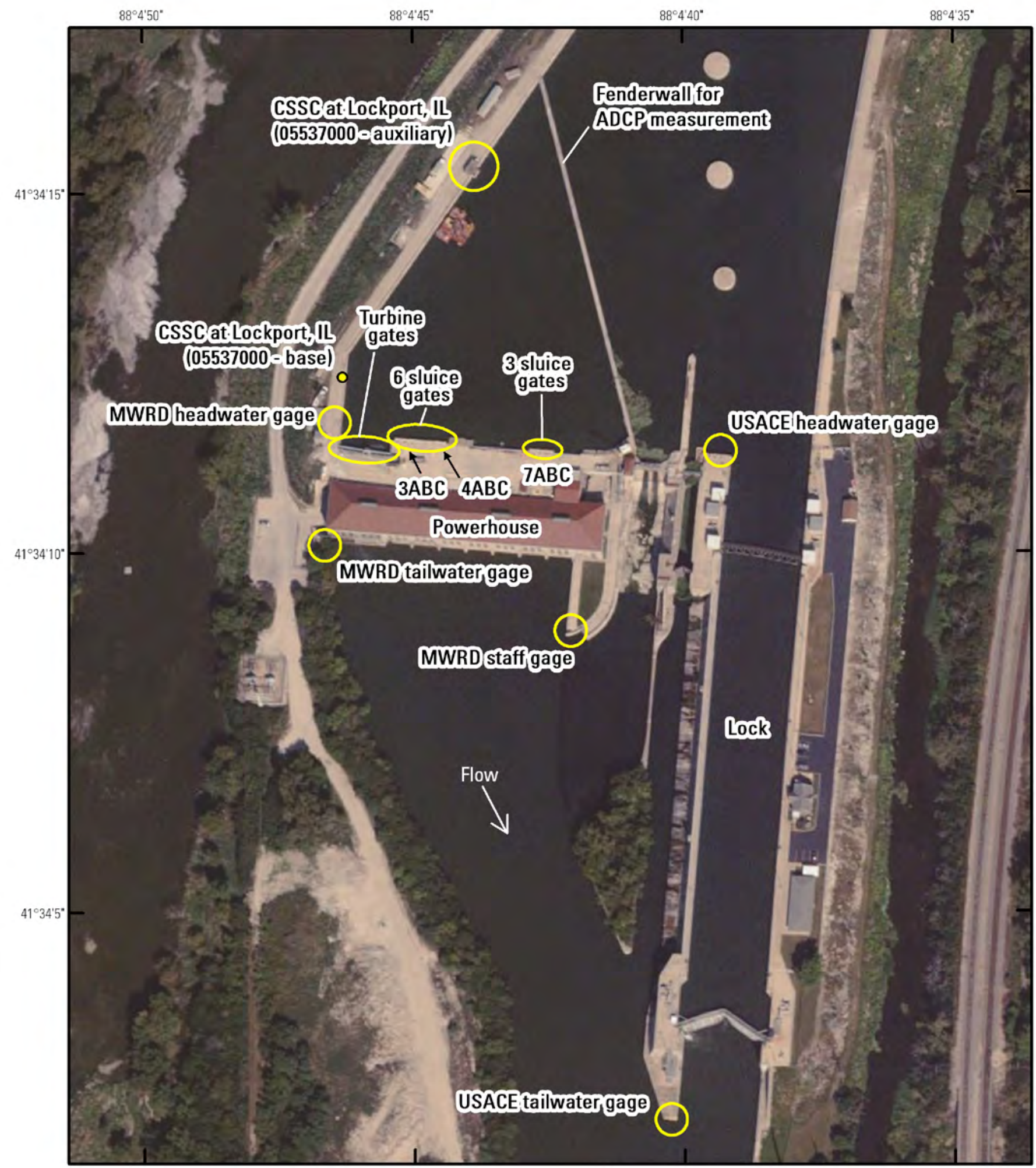

Digital imagery from Aerials Express, 2009

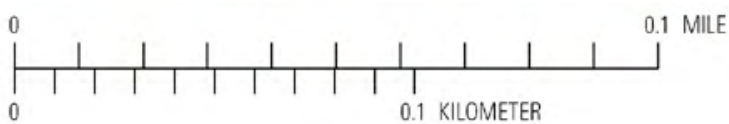

Figure 12. Aerial image of Lockport Powerhouse structures and headwater and tailwater gages. [CSSC, Chicago Sanitary and Ship Canal; ADCP, acoustic Doppler current profiler; MWRD, Metropolitan Water Reclamation District; USACE, U.S. Army Corps of Engineers] 


\section{Approach}

ADCP measurements were made at the Lockport Powerhouse structures with a tethered boat on the concrete walkway shown in figures 12 and 13. The USGS CSSC-LPH headwater gage (auxiliary sensor located outside the drawdown zone) and USACE tailwater gage (fig. 12) were used for stage readings.

A review of existing ratings and comparison of computed and measured flows was performed. Development of new ratings was to be attempted with standard control-structure techniques (Chow, 1959; Collins, 1977; Roberson and others, 1998), but gate openings were configured in several ways during the nine measurements. The lack of consistent gate configuration precluded the development of new equations; however, comparison of measured and computed flow using the Hart and McGee (1985) and Muga (1961) methods gives insight into the accuracy of the computed values.

\section{Measurement Summary}

Streamflow and stage data were collected on the CSSC at the powerhouse during March-November 2010 at the following location (fig. 12):

- $\quad$ CSSC at Lockport (CSSC-LPH) (05537000) (powerhouse gage)

- Location: Headwater elevations for the controlling works

- Data: Continuous stage, discrete streamflow measurements

The continuous data are available from the NWIS database at the USGS Illinois Water Science Center. The discrete flow measurements for the CSSC-LPH gage are presented in table 5. During an approximately 6-month period, there were 11 measurements ranging from 1,118 to $8,160 \mathrm{ft}^{3} / \mathrm{s}$ at CSSCLPH. Measurements 1 and 2, made on May 13, 2010, were not usable because flow turbulence pushed the boat against the fenderwall, and the acoustic beams from the ADCP were reflecting off of the arched walls resulting in biased velocity data. The measurement method was adjusted for the remainder of measurements by attaching the ADCP to a rope stretched across the basin to prevent it from moving too close to the arched walls. Additional measurements were made during a high-flow event in November 2010 replacing the unusable measurements in May. The three sluice gates that were undergoing repairs during previous measurements (7A, B, and C), were operational and utilized during the November event. Stream conditions at the powerhouse on July 24, 2010, when 6 of the 9 sluice gates and both turbines were in operation, are shown in figure 15 .

\section{Results}

Development of new rating equations for the powerhouse control structures was attempted using standard controlstructure techniques, but the lack of consistent gate configuration precluded the development of new equations. However, comparison of measured and computed flow using the Hart and McGee (1985) and Muga (1961) methods gives insight into the accuracy of the methods. Note that in the powerhouse measurements, the change in canal WSE was less than $0.3 \mathrm{ft}$ for all measurements - except measurement 8-where the canal dropped by more than $1 \mathrm{ft}$ (table 5). Also, note the changes being made to the gates and turbine malfunction in measurements $8-10$ as footnoted in table 5. Considering the extenuating conditions, if additional measurements were made, measurements $8-10$ could possibly be omitted, but are left in this analysis as they add value to the comparison of measured and computed flows.

Nine measurements, ranging from 1,118 to $8,160 \mathrm{ft}^{3} / \mathrm{s}$, were used to compare with USACE (sluice gates) and MWRD (turbine) computed flows (table 5 and fig. 16). Turbine flow was computed by MWRD by back-calculating flow from power production. All four measurements taken while there was only turbine flow have computed MWRD turbine flows within 30 percent of measured flows. For the five measurements made while there was both turbine and sluice-gate flow, the computed USACE and MWRD flows range from 10 to more than 100 percent different than measured flows. 

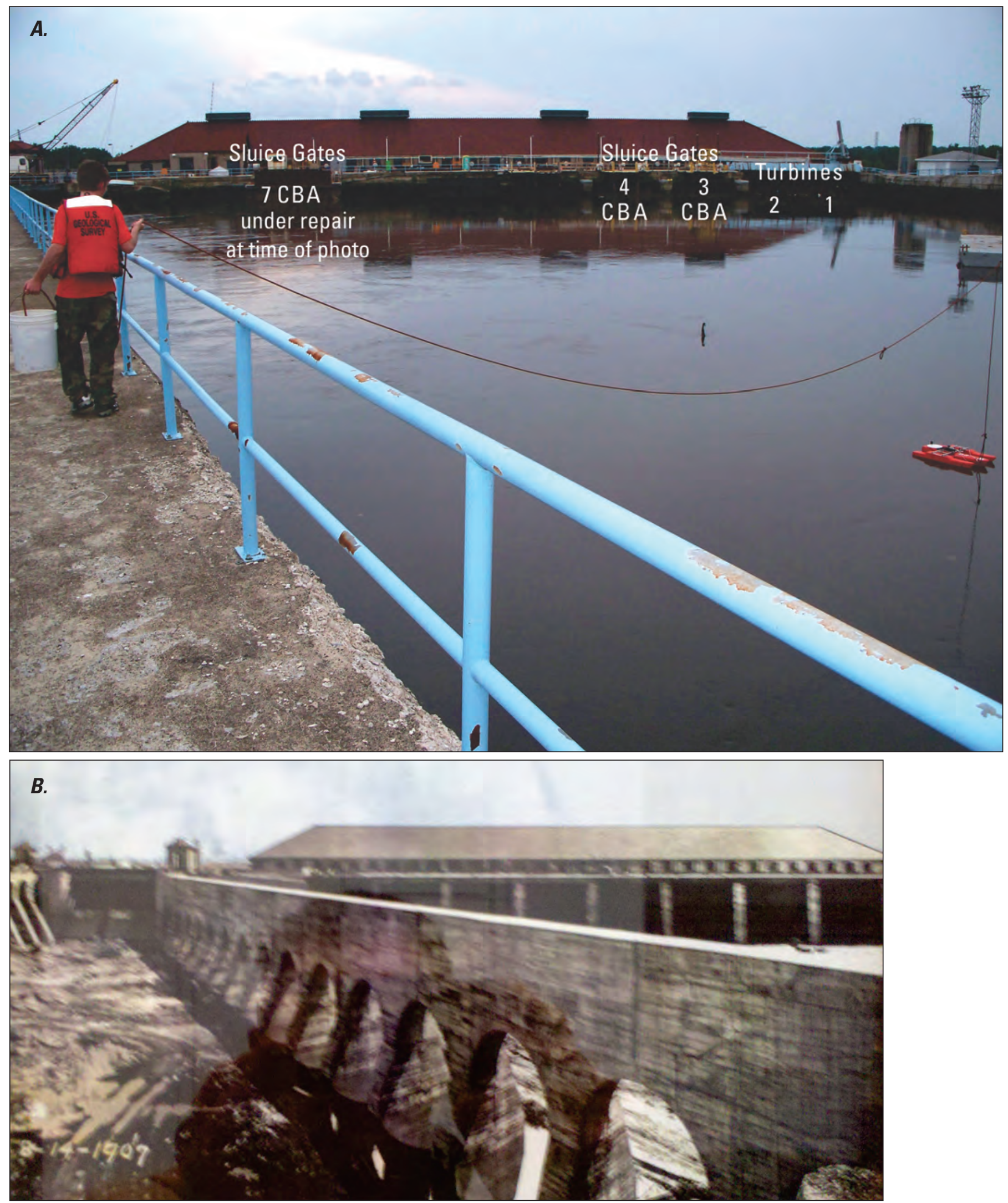

Figure 13. Photographs showing Lockport Powerhouse structures. $A$, view looking downstream at structure and acoustic Doppler current profiler measurement being made on July 24, 2010, utilizing the fenderwall. $B$, fenderwall during dry conditions in 1907. 
Table 5. Flow measurements during the study period for the U.S. Geological Survey streamflow-gaging station at the Chicago Sanitary and Ship Canal at Lockport (CSSC-LPH), Illinois (05537000), and computed flows from Hart and McGee (1985) and the Metropolitan Water Reclamation District.

[USGS, U.S. Geological Survey; CST, central standard time; fts/s, cubic foot per second; HW, headwater; ft, foot; TW, tailwater; USACE, U.S. Army Corps of Engineers; C/M,computed flow divided by measured flow; - , not applicable]

\begin{tabular}{|c|c|c|c|c|c|c|c|c|c|c|c|c|c|}
\hline \multirow{3}{*}{$\begin{array}{c}\text { USGS } \\
\text { measure- } \\
\text { ment } \\
\text { number }\end{array}$} & \multirow[b]{3}{*}{ Date } & & & \multirow{3}{*}{$\begin{array}{l}\text { Measured } \\
\text { total } \\
\text { streamflow } \\
(\mathrm{M})\left(\mathrm{ft}^{3} / \mathrm{s}\right)\end{array}$} & \multirow{3}{*}{$\begin{array}{c}\text { HW } \\
\text { Stage }^{5} \\
\text { USGS } \\
(\mathrm{HW})(\mathrm{ft})\end{array}$} & \multirow{3}{*}{$\begin{array}{l}\text { Change in } \\
\text { HW for } \\
\text { duration } \\
\text { (ft) }\end{array}$} & \multirow{3}{*}{$\begin{array}{c}\text { TW } \\
\text { stage }^{5} \\
\text { USACE } \\
\text { (TW) (ft) }\end{array}$} & \multicolumn{2}{|c|}{ Sluice gates } & \multicolumn{2}{|c|}{ Turbine } & \multirow{3}{*}{$\begin{array}{c}\text { Computed } \\
\text { total flow } \\
\text { (C) } \\
(\mathrm{C}=\mathrm{T}+\mathrm{S}) \\
\left(\mathrm{ft}^{3} / \mathrm{s}\right)\end{array}$} & \multirow[b]{3}{*}{$\mathrm{C} / \mathrm{M}$} \\
\hline & & \multicolumn{2}{|c|}{ Time (CST) } & & & & & Gate & Computed $^{6}$ & Config- & Computed $^{7}$ & & \\
\hline & & Start & End & & & & & uration & $\left(\mathrm{ft}^{3} / \mathrm{s}\right)$ & & $\left(\mathrm{ft}^{3} / \mathrm{s}\right)$ & & \\
\hline 3 & $07 / 24 / 2010$ & $16: 49$ & $17: 36$ & 8,160 & -8.41 & -0.03 & -37.51 & $\begin{array}{r}3 \mathrm{ABC}, \\
4 \mathrm{ABC}\end{array}$ & 13,906 & 1,2 & 3,000 & 16,906 & 2.1 \\
\hline 4 & $07 / 24 / 2010$ & $18: 35$ & $19: 15$ & 8,000 & -8.45 & -.04 & -37.52 & $\begin{array}{l}3 \mathrm{ABC} \\
4 \mathrm{ABC}\end{array}$ & 13,894 & 1,2 & 3,000 & 16,894 & 2.1 \\
\hline 5 & $07 / 26 / 2010$ & 07:02 & $08: 27$ & 2,460 & -3.53 & .01 & -39.24 & - & 0 & 1 & 2,300 & 2,300 & .9 \\
\hline 6 & $07 / 26 / 2010$ & $13: 33$ & $15: 07$ & 2,280 & -2.93 & .21 & -39.48 & - & 0 & 1,2 & 3,000 & 3,000 & 1.3 \\
\hline 7 & $08 / 23 / 2010$ & $14: 35$ & $15: 24$ & 1,118 & -2.74 & -.27 & -40.46 & - & 0 & 1 & 1,000 & 1,000 & .9 \\
\hline${ }^{2} 8$ & $11 / 23 / 2010$ & 10:06 & $11: 31$ & 4,494 & -3.54 & -1.15 & -41.82 & 7B & 2,561 & 1 & 1,500 & 4,061 & .9 \\
\hline 3,49 & $11 / 23 / 2010$ & $11: 31$ & $12: 42$ & 4,224 & -3.93 & -.15 & -41.59 & $7 \mathrm{BC}$ & 5,017 & 1 & 1,500 & 6,517 & 1.5 \\
\hline${ }^{4} 10$ & $11 / 23 / 2010$ & $12: 43$ & $13: 46$ & 6,038 & -4.35 & -.05 & -41.48 & $7 \mathrm{ABC}$ & 7,822 & - & 0 & 7,822 & 1.3 \\
\hline 11 & $11 / 23 / 2010$ & $14: 53$ & $14: 58$ & 2,165 & -4.38 & .28 & -41.00 & - & 0 & 1,2 & 2,400 & 2,400 & 1.1 \\
\hline
\end{tabular}

${ }^{1}$ Measurements 1 and 2 on May 13, 2010, were not usable because flow turbulence pushed the boat against the fenderwall and the beams were hitting the arched walls (method was adjusted for the remainder of measurements).

${ }^{2}$ Sluice Gate 7B opened during measurement, and prior to measurement barge went through lock (upstream to downstream).

${ }^{3}$ Sluice Gate $7 \mathrm{C}$ opened during measurement.

${ }^{4}$ Turbines stopped operating during measurement 9 and were not operating during all of measurement 10, per USGS field note.

${ }^{5}$ Averaged over the time of the measurement.

${ }^{6}$ Sluice gate computation information from Hart and McGee, 1985.

${ }^{7}$ Determined by Metropolitan Water Reclamation District. 
A side-view schematic of the sluice gates and parameters used in the rating evaluation by Hart and McGee (1985) are shown in figure 14. The three flow conditions and equations as described in the 1985 study are

\begin{tabular}{lc}
\hline \multicolumn{1}{c}{ Condition } & Equation \\
\hline $\begin{array}{l}\text { Sluice-gate control: } \\
\text { (no tailwater effect) }\end{array}$ & $Q=C A \sqrt{2 g H_{1}}$ \\
$\begin{array}{l}\text { Draft-tube control: } \\
\text { (tailwater effect) }\end{array}$ & $Q=C^{\prime} A \sqrt{2 g \Delta H}$ \\
$\begin{array}{l}\text { Critical flow: } \\
\text { (no tailwater effect) }\end{array}$ & $Q=3.09 w H_{1}^{3 / 2}$
\end{tabular}

where

$Q \quad$ is discharge, in $\mathrm{ft}^{3} / \mathrm{s}$;

$C$ is discharge coefficient, sluice gate;

$A$ is gate area, in $\mathrm{ft}^{2}$;

$g$ is gravitational acceleration constant, 32.2, in $\mathrm{ft}^{2} / \mathrm{s}$;

$H_{1} \quad$ is total upstream head on the gate sill, in $\mathrm{ft}$;

$C^{\prime} \quad$ is discharge coefficient, overall structure;

$\Delta H \quad$ is total head loss, in $\mathrm{ft}$; and

$w \quad$ is gate width, in $\mathrm{ft}$.
Note that equation 14 is one form of a submerged sluice-gate orifice flow equation, and that $\Delta H$ is the head loss from the canal headwater to the canal tailwater as shown in figure 14. However, Chow (1959) stated the following regarding the orifice equations:

"For the purpose of experimental studies, ... The form of this equation is the same for both free and submerged flows."

In other words, to develop the submerged-orifice equation (equation 14); Chow (1959) and Roberson and others (1998) show the same orifice equation for free and submerged flows $Q=C A \sqrt{2 g H_{1}}$, and this approach was successfully applied in Straub and others (2009). Essentially, $\Delta H$ is not used in the submerged-flow equation; however, the determination of the coefficient value is based on the relation of the $H_{1}$ to the tailwater elevation. Also, any submergence coefficient or $\Delta H$ calculation should most likely consider the tailwater elevation in the chamber before the flow enters the draft tubes (figs. 14 and 17) (instead of the canal tailwater).

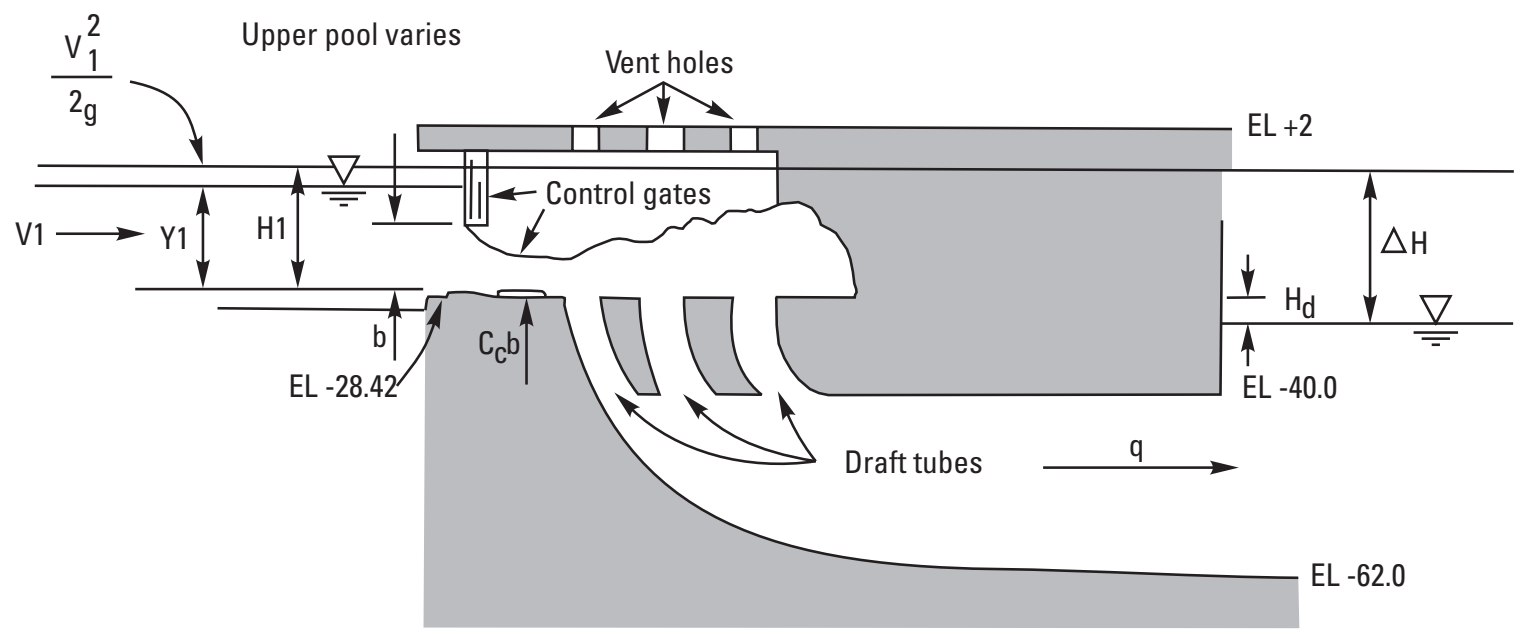

Figure 14. Lockport bay section showing the intricacies of flow (modified from Hart and McGee, 1985) 

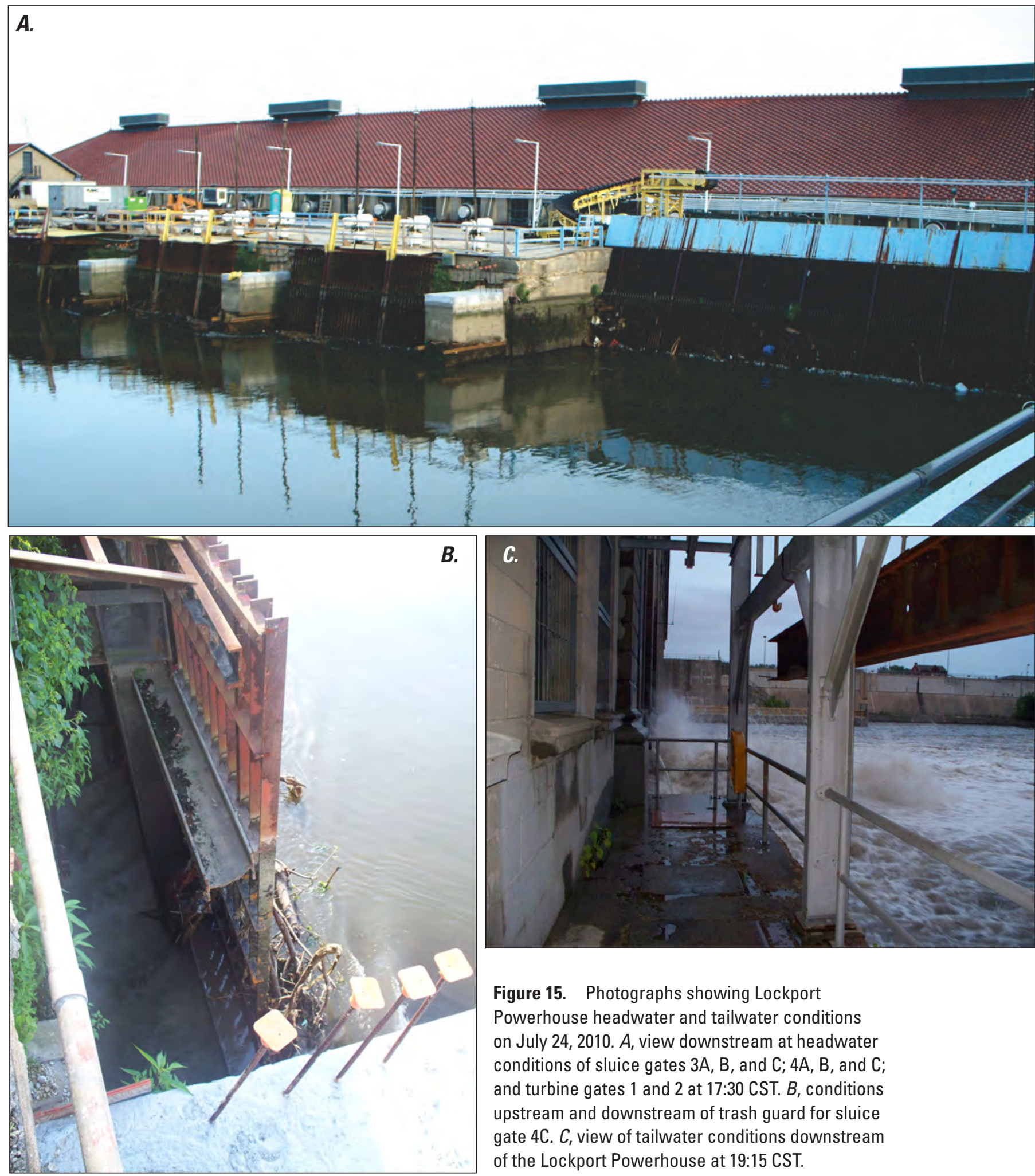

Figure 15. Photographs showing Lockport

Powerhouse headwater and tailwater conditions on July 24, 2010. $A$, view downstream at headwater conditions of sluice gates $3 A, B$, and $C ; 4 A, B$, and $C$; and turbine gates 1 and 2 at 17:30 CST. $B$, conditions upstream and downstream of trash guard for sluice gate $4 C$. $C$, view of tailwater conditions downstream of the Lockport Powerhouse at 19:15 CST. 


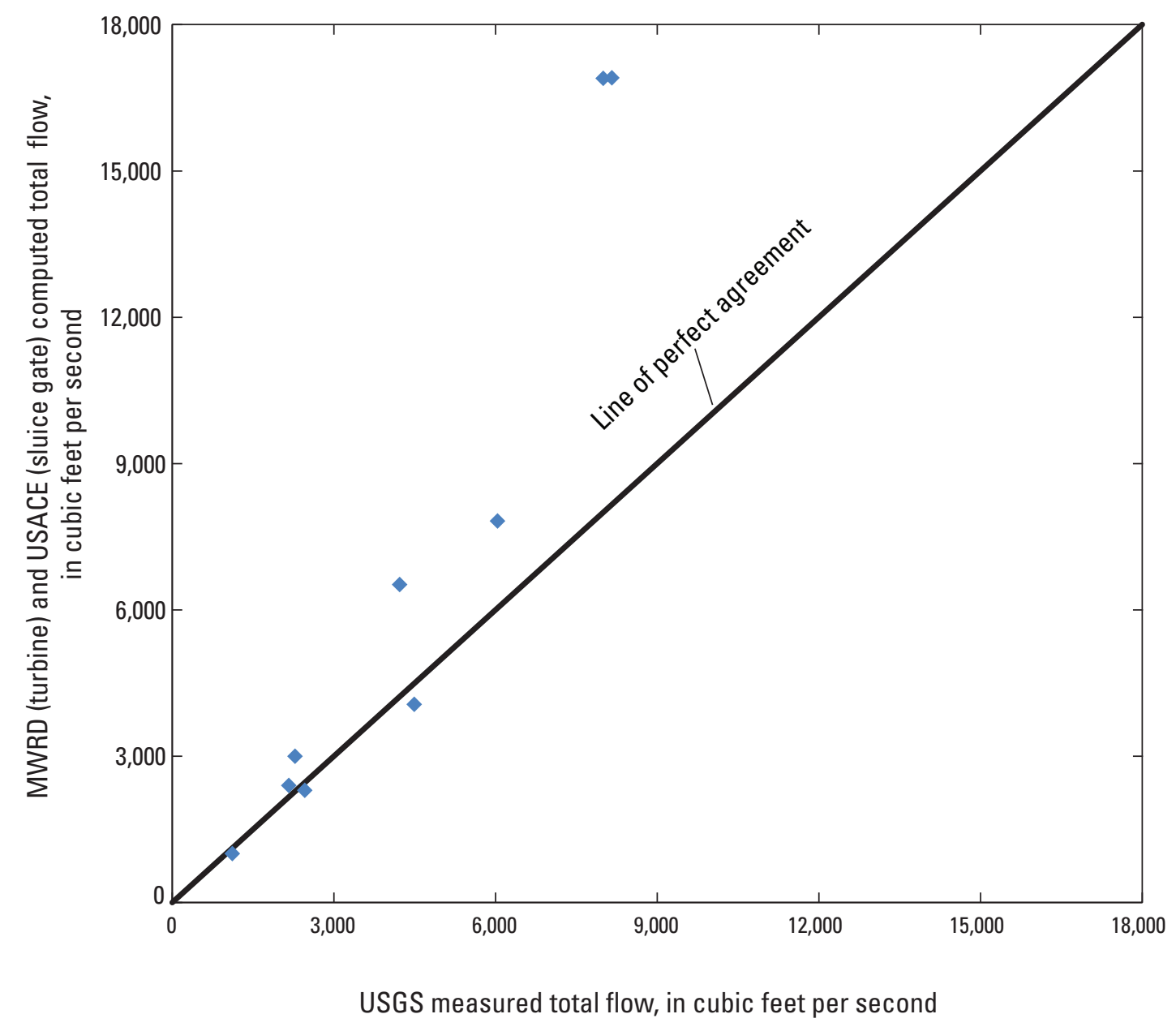

Figure 16. Measured and computed flows for the Lockport Powerhouse on the Chicago Sanitary and Ship Canal near Lockport, Illinois. [MWRD, Metropolitan Water Reclamation District of Greater Chicago; USACE, U.S. Army Corps of Engineers; USGS, U.S. Geological Survey] 

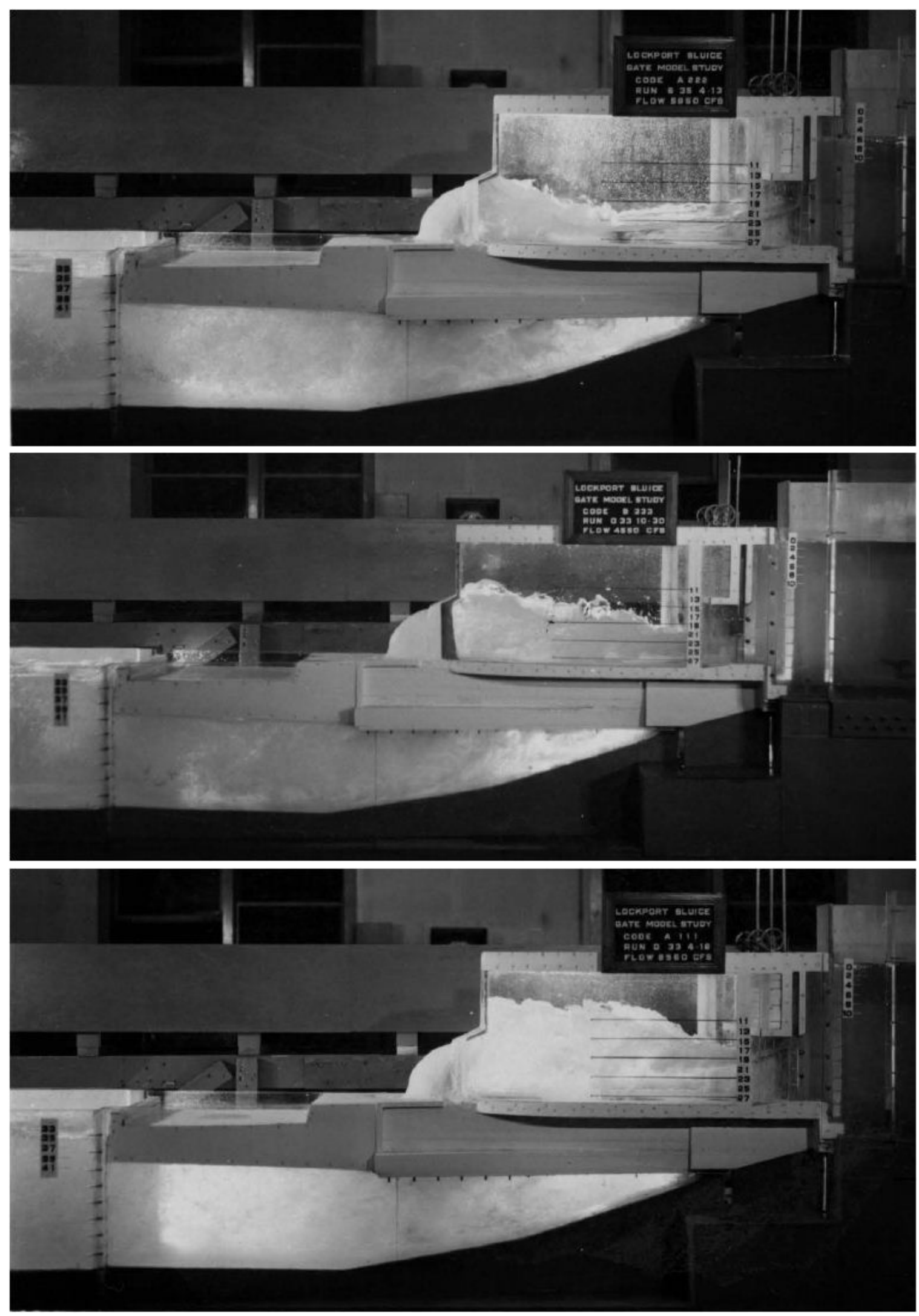

Figure 17. Selected photographs (from Muga, 1961) showing Lockport Powerhouse flow conditions as modeled by Muga, 1961. 


\section{Potential Future Work}

The results presented in this report are for conditions observed during a period of less than one year. If additional conditions were to be measured, potential suggestions for how to build on the results from this study are outlined in the following sections.

\section{Controlling Works}

- Tailwater comparisons

- Compare stages at three locations: DPR-L gage, MWRD tailwater gage, and the recommended tailwater location (Hart and McGee, 1985); then evaluate submergence coefficients

- Measure flow when various numbers of gates are open

- Measure flow from the catwalk on the downstream side of the structure

- Conditions exist (figs. 5 and 6) such that a tethered boat can be launched from the structure itself and not only complement the continuous data from the two Des Plaines River gages, but also give additional information on the flow through each gate

- Measure diverted flow for a broader range of canal WSE elevations

- Lower the canal WSE using the controlling works instead of the powerhouse so that the new ratings can be extended

\section{Powerhouse}

- Measure flow for a broader range of canal elevations and systematic gate operations

- Measure tailwater below the vent holes (figs. 14 and 17)

- Reevaluate the submergence equations for the powerhouse using the proposed new data and data from the Muga (1961) study.

- Devise a system for continuous measurement of flow (index-velocity rating methods) at the powerhouse

\section{Summary}

The U.S. Army Corps of Engineers (USACE) and the Metropolitan Water Reclamation District of Greater Chicago (MWRD) regulate flows through control structures along the Lake Michigan lakefront and the Chicago Sanitary and Ship Canal (CSSC). New acoustic technologies for measuring velocity and flow are being used to determine flow for Lake Michigan diversion accounting, flood control, sanitary, and navigation purposes. These advanced technologies provide an opportunity to evaluate the ratings for flow through the control structures near Lockport, Illinois. The evaluation and analysis were done in 2010 and 2011 by the U.S. Geological Survey (USGS), in cooperation with the USACE.

The LCW is located 2.1 miles upstream of the Lockport Lock and Powerhouse. The drainage area at the headwater gage (05536998 CSSC-LCW, Illinois) is 739.5 square miles $\left(\mathrm{mi}^{2}\right)$. The structure consists of seven 30 -feet (ft) wide sluice gates and is used to divert water from the CSSC into the Des Plaines River. The flow regimes for the sluice gate included both free and submerged weir. Forty and 491 flow values from U.S. Geological Survey streamflow-gaging stations were used to describe free- and submerged-weir flow, respectively, through the sluice gates. The equations were developed for canal headwater elevations ranging from -7.0 to $-10.5 \mathrm{ft}$ Chicago City Datum (CCD), and tailwater (Des Plaines River at Lockport) to headwater (CSSC-LCW-Base) ratios ranging from 0.31 to 0.66 .

The Lockport Powerhouse is located adjacent to the Lockport Lock. The drainage area at the headwater gage (05537000 CSSC-LPH, Illinois) is $740 \mathrm{mi}^{2}$. The structure consists of nine 9 -ft wide by $14-\mathrm{ft}$ high sluice gates and two $10-\mathrm{ft}$ diameter turbines. Both tailwater and no tailwater effect flow regimes occurred during nine measurements. Also, the canal headwater elevations ranged from -2.74 to $-8.45 \mathrm{ft}$ $\mathrm{CCD}$, and the gates were configured six different ways during the measurements. 


\section{References Cited}

Aerials Express (Chicago Imagery), 2009, ArcGIS Map Service, http://services.arcgisonline.com/arcgis/services/.

Chow, V.T., 1959, Open-channel hydraulics: New York, McGraw-Hill, $680 \mathrm{p}$.

Collins, D.L., 1977, Computation of records of streamflow at control structures: U.S. Geological Survey Water-Resources Investigations Report 77-8, $57 \mathrm{p}$.

Hart, E.D., and McGee, R.G., 1985, Lockport power plant sluice gate and control works discharge evaluation: U.S. Army Engineer Waterways Experiment Station Hydraulics Laboratory Miscellaneous Paper HL-85-4, 105 p.

Morlock, S.E., Nguyen, H.T., and Ross, J.H., 2002, Feasibility of acoustic Doppler velocity meters for the production of discharge records from U.S. Geological Survey streamflowgaging stations: U.S. Geological Survey Water-Resources Investigations Report 01-4157, 56 p., accessed February 13, 2011, at http://pubs.usgs.gov/wri/2001/wri01_4157/.

Muga, B.J., 1961, The Lockport sluice gate model study: Urbana, University of Illinois, Department of Civil Engineering, M.S. thesis, $111 \mathrm{p}$.

Roberson, J.A., Cassidy, J.J., and Chaudhry, M.H., 1998, Hydraulic engineering ( $2 \mathrm{~d}$ ed.): New York, Wiley, $653 \mathrm{p}$.

Ruhl, C.A., and Simpson, M.R., 2005, Computation of discharge using the index-velocity method in tidally affected areas: U.S. Geological Survey Scientific Investigations Report 2005-5004, 41 p., accessed February 13, 2012, at http://pubs.usgs.gov/sir/2005/5004/.

Straub, T.D., Johnson, G.P., Hortness, J.E., and Parker, J.R., 2009, Control-structure ratings on the Fox River at McHenry and Algonquin, Illinois: U.S. Geological Survey Scientific Investigations Report 2009-5186, 61 p., accessed February 13, 2012, at http://pubs.usgs.gov/sir/2009/5186/.

Turnipseed, D.P., Sauer, V.B., Discharge measurements at gaging stations: U.S. Geological Survey Techniques and Methods book 3, chap. A8, 87 p. (Also available at http:// pubs.usgs.gov/tm/tm3-a8.)

U.S. Department of Agriculture, 2011, Farm Service Agency, National Agriculture Imagery Program (NAIP), ArcGIS Map Service, http://gis.apfo.usda.gov/arcgis/services/. 



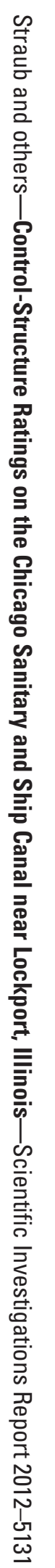

